\title{
Crystal Structure and Subsequent Ligand Design of a Nonriboside Partial Agonist Bound to the Adenosine $A_{2 A}$ Receptor
}

\author{
Tasia Amelia, Jacobus P. D. van Veldhoven, Matteo Falsini, Rongfang Liu, Laura H. Heitman,
} Gerard J. P. van Westen, Elena Segala, Grégory Verdon, Robert K. Y. Cheng, Robert M. Cooke, Daan van der Es, and Adriaan P. IJzerman*

Cite This: J. Med. Chem. 2021, 64, 3827-3842

Read Online

\section{ACCESS \\ WIII Metrics \& More \\ Article Recommendations \\ Supporting Information}

ABSTRACT: In this study, we determined the crystal structure of an engineered human adenosine $\mathrm{A}_{2 \mathrm{~A}}$ receptor bound to a partial agonist and compared it to structures cocrystallized with either a full agonist or an antagonist/inverse agonist. The interaction between the partial agonist, belonging to a class of dicyanopyridines, and amino acids in the ligand binding pocket inspired us to develop a small library of derivatives and assess their affinity in radioligand binding studies and potency and intrinsic activity in a functional, label-free, intact cell assay. It appeared that some of the derivatives retained the partial agonist profile, whereas other ligands turned into inverse agonists. We rationalized this remarkable behavior with additional computational docking studies.

\section{INTRODUCTION}

Human adenosine receptors, of which there are four subtypes

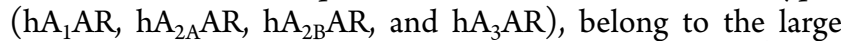
superfamily of $G$ protein-coupled receptors (GPCRs). ${ }^{1}$ The $\mathrm{hA}_{2 \mathrm{~A}} \mathrm{AR}$ was one of the first GPCRs crystallized; ${ }^{2,3}$ multiple structures are available now, both with antagonists/inverse agonists or (full) agonists bound. ${ }^{4}$ Typically and unlike prototypic antagonists such as ZM241385, agonists such as adenosine itself bear a ribose moiety, which is deemed critical for agonist activity (Figure 1)..$^{5}$ The latter dogma was challenged by a series of dicyanopyridines without a ribose group, discovered, and further developed in the Bayer laboratories as partial agonists predominantly for the $\mathrm{hA}_{1} \mathrm{AR}^{6,7} \mathrm{~A}$ recent phase $2 \mathrm{~b}$ clinical trial with one of these compounds, neladenoson, failed to meet the primary endpoint in patients with heart failure, however. ${ }^{8}$ Depending on the substitution pattern of these pyridine derivatives, affinity for $A_{2 A}$ and $A_{2 B}$ receptors can be achieved as well. Colotta and coworkers synthesized a number of derivatives with high affinity for $\mathrm{hA}_{2 \mathrm{~B}} \mathrm{AR},{ }^{9}$ while $\mathrm{BAY}$ 60-6583 was reported to be a partial agonist for $A_{2 B} A R .^{10}$ We ourselves synthesized 8 (LUF5833) and LUF5834 (Figure 1) with appreciable affinity for the adenosine $A_{2 \mathrm{~A}}$ receptor and partial agonistic activity on this receptor subtype. ${ }^{11,12}$

In this study, we present the crystal structure of $\mathbf{8}$ bound to an engineered construct of the adenosine $A_{2 A}$ receptor and compare this structure with those of antagonist- and agonistbound receptors. We then synthesized a series of derivatives of 8 (Figure 1) inspired by the compound's interaction with specific amino acids in the binding pocket of the receptor. These novel compounds were evaluated in radioligand binding studies to assess their affinity for the (four) adenosine receptor subtypes. We also tested these compounds in a label-free impedance-based assay to determine their intrinsic activity on the $A_{2 A}$ receptor, revealing a huge variation in efficacy, in between agonism and inverse agonism. Further docking studies shed light on the atomic/structural features responsible for this behavior.

\section{RESULTS}

Structure of the Compound 8-Receptor Complex. To obtain crystals of the compound 8-receptor complex, we used an existing thermostabilized receptor construct combined with a bRIL fusion protein, coined $\mathrm{A}_{2 \mathrm{~A}}-\mathrm{StaR2}$-bRIL, ${ }^{13}$ and a previously described approach in which crystals of $\mathrm{A}_{2 \mathrm{~A}^{-}}$ StaR2-bRIL were formed with theophylline. ${ }^{14}$ After soaking the crystals with 8 , they were exposed to synchrotron X-ray radiation and diffraction data collected to $3.1 \AA$ resolution (Figure 2A and Figure S1A). Following initial rounds of refinement using the receptor only, both residual $2 F_{o}-F_{c}$ and $F_{\mathrm{o}}-F_{\mathrm{c}}$ electron density maps (Figure $\mathrm{S} 1 \mathrm{~B}$ ) revealed clearly the entire pose of $\mathbf{8}$ and most surrounding side chains lining the binding site.

Compound 8 adopts an extended pose in the orthosteric binding site of $\mathrm{hA}_{2 \mathrm{~A}} \mathrm{AR}$, engaging many of the residues

Received: November 11, 2020

Published: March 25, 2021 
<smiles>Nc1ncnc2c1ncn2[C@@H]1O[C@H](CO)[C@@H](O)[C@H]1O</smiles>

adenosine<smiles>Nc1nc(NCCc2ccc(O)cc2)nc2nc(-c3ccco3)nn12</smiles>

ZM241385<smiles>N#Cc1c(N)nc(SCc2ncc[nH]2)c(C#N)c1-c1ccccc1</smiles>

LUF5833 (8)<smiles>N#Cc1c(N)nc(SCc2ncc[nH]2)c(C#N)c1-c1ccc(O)cc1</smiles><smiles>N#Cc1c(N)nc(SCc2ncc[nH]2)nc1-c1ccccc1</smiles>

1<smiles>N#Cc1c(-c2ccccc2)cc(SCc2ncc[nH]2)nc1N</smiles><smiles>Nc1nc(SCc2ncc[nH]2)nc(-c2ccccc2)n1</smiles>

2<smiles>Nc1cc(-c2ccccc2)cc(SCc2ncc[nH]2)n1</smiles><smiles>N#Cc1c(SCc2ncc[nH]2)nc(N)nc1-c1ccccc1</smiles><smiles>N#Cc1c(-c2ccccc2)cc(N)nc1SCc1ncc[nH]1</smiles>

Figure 1. Chemical structures of adenosine, the nonriboside partial agonists 8 (LUF5833) and LUF5834, inverse agonist/antagonist ZM241385, and the derivatives of 8 synthesized in this study $(\mathbf{1}-\mathbf{6})$.

previously described as interacting with agonists and antagonists $^{13}$ (Figure 2B). The imidazole substituent lies nearest the extracellular face in a pocket lined by the side

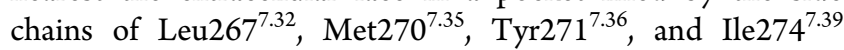
(superscript numbering according to Ballesteros and Weinstein $\left.^{15}\right)$. The pyridine core is positioned similarly to the adenine moiety in NECA, lying between Ile274 ${ }^{7.39}$ and Phe $168^{5.29}$, and the phenyl group lies deepest in the receptor, similar to the ribose of adenosine, contacting Trp246 and forming a $\pi-\pi$ interaction with Phe $168^{5.29}$. One cyano substituent forms a hydrogen bond with Asn $253^{6.55}$ and the exocyclic amine interacts with Asn253 $3^{6.55}$ and Glu169 ${ }^{\mathrm{EL} 2}$.

Among the 19 amino acids close $(<4 \AA$ ) to 8 (Figure 2C), Ser2 $27^{7.42}$ (Ala in $\mathrm{A}_{2 \mathrm{~A}}$-StaR2-bRIL; see Discussion and Conclusions) and His $278^{7.43}$ have been found crucial for full agonist binding. ${ }^{16,17}$ For a further analysis of the latter, we compared this structure with two reference $A_{2 A}$ receptor structures, one antagonist/inverse agonist (ZM241385)-bound (PDB ID: 5IU4) ${ }^{13}$ and the other agonist (NECA)-bound (PDB ID: 2YDV) ${ }^{18}$ (Figures S2 and S3). The overall compound 8 and ZM241385 receptor structures were very similar (protein-protein RMSD, $0.65 \AA$ ), not unexpectedly since the same receptor construct was used in both. However, the amino acids making up the binding pocket of ZM241385 do not include "agonistic" Ser277.42 and His $278^{7.43}$, validating the antagonistic nature of ZM241385 (Figures S2A and S3A). Contrarily, the binding pocket around NECA's ribose moiety does include these two amino acids next to, e.g., Thr88 $8^{3.36}$, another amino acid known to be involved in full agonist activation $^{16,19}$ (Figures $2 \mathrm{~B}$ and $3 \mathrm{~B}$ ). Although far from being conclusive on the basis of $3 \mathrm{D}$ architecture alone, this comparison between the three receptor structures suggests that the binding pocket of $\mathbf{8}$ shares characteristics of both agonist- and antagonist-occupied receptors. Hence, we decided to synthesize six derivatives of $\mathbf{8}$ to shed further light on the compound's agonistic/antagonistic behavior.

Synthesis of Compound 8 Derivatives. In these derivatives, the cyano groups and the number of nitrogen atoms in the core were varied (compounds 1-6, Figure 1). Due to the targeted change in the core scaffold, a different synthetic pathway was used for every analogue of 8 . The synthesis routes toward the pyrimidine and triazine derivatives are shown in Scheme 1.

Compound 1 was synthesized starting with a multicomponent reaction between benzaldehyde (9), malononitrile, and thiourea, forming intermediate $10^{20}$ Then, 2-bromome- 

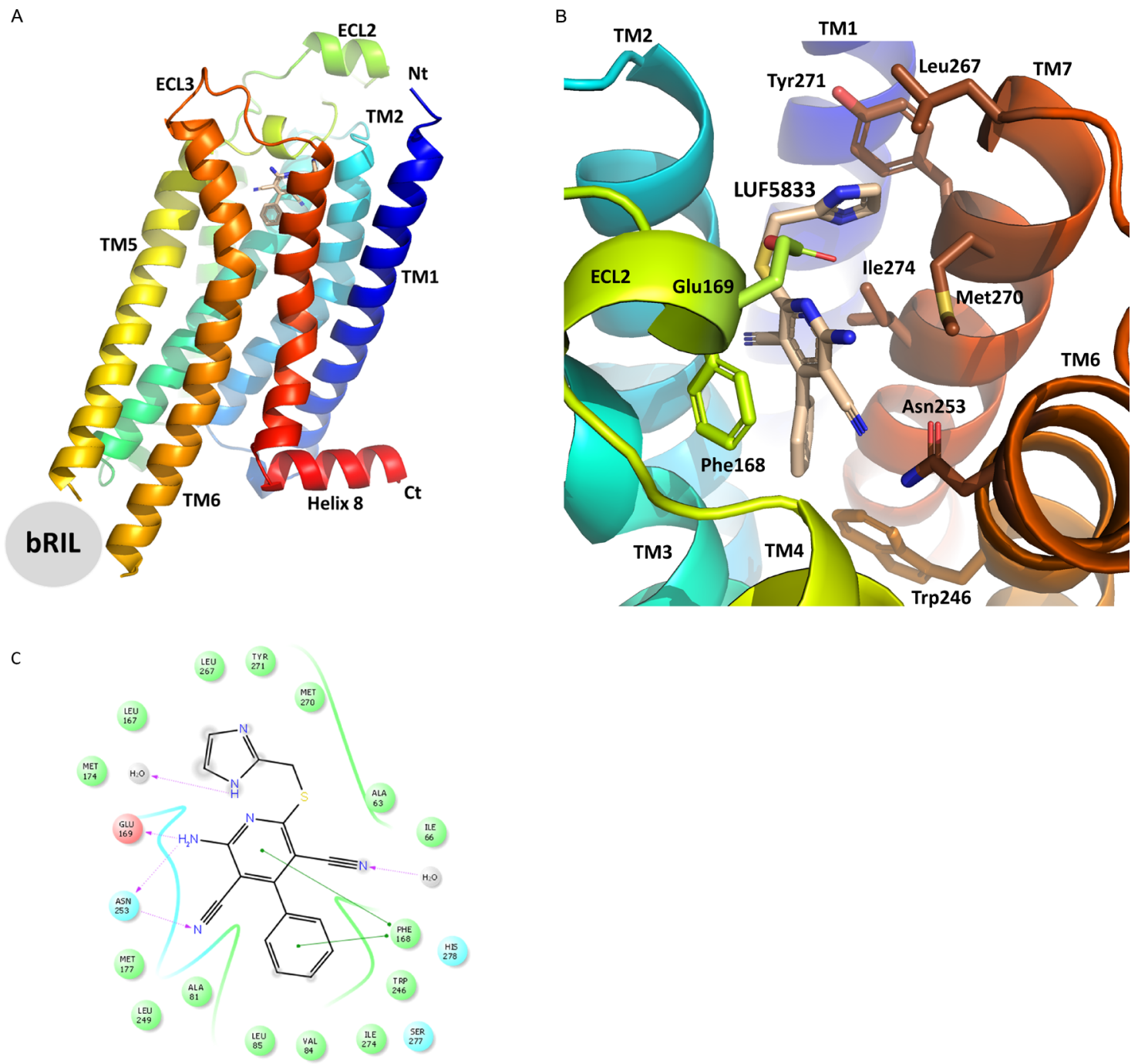

Figure 2. (A) Crystal structure of stabilized $\mathrm{hA}_{2 \mathrm{~A}} \mathrm{AR}-\mathrm{STaR2}$-bRIL in complex with partial agonist 8 (color-coded according to protein domains; TM: transmembrane domain; ECL: extracellular loop; Nt: N-terminus; $\mathrm{Ct}$ : C-terminus; bRIL structure omitted for clarity; compound 8 within TM cavity); (B) ligand binding site of 8 (LUF5833) surrounded by amino acids (three-letter code) within 4 A distance; (C) two-dimensional representation of interacting amino acids and 8 docked into the $\mathrm{hA}_{2 \mathrm{~A}} \mathrm{AR}$ crystal structure with all nine thermostabilizing mutations reverted to wildtype $\mathrm{hA}_{2 \mathrm{~A}} \mathrm{AR}$, showing the ligand binding cavity within the $4 \AA$ distance of $\mathbf{8}$ (green circle: hydrophobic; red circle: negatively charged; blue circle: polar; gray circle: water; gradient gray circle: solvent exposed).

thylimidazole (7) was synthesized by reducing the commercially available 2 -imidazolecarboxaldehyde with sodium borohydride in absolute ethanol. Subsequent treatment with hydrobromic acid (33\% in acetic acid) furnished the commonly used alkylating agent $7 .^{11,21}$ Alkylation of intermediate $\mathbf{1 0}$ with agent 7 gave cyanopyrimidine $\mathbf{1}$ in a satisfactory $40 \%$ yield. The synthesis of 2 was started from the commercially available cyanuric chloride 11. Grignard alkylation with phenylmagnesium bromide provided $\mathbf{1 2}$ in a relatively good yield of $52 \%$. Amination was then performed using 1.0 equiv of concentrated aqueous ammonia to give crude 13 . $^{22}$ This was treated with an excess of sodium sulfide nonahydrate to furnish the crystalline intermediate 14, which was alkylated using 7 to give the final compound 2. Although compounds 1 and 3 are both cyanopyrimidine derivatives, the synthesis of compound 3 , in which the cyano group has an opposed topology, was slightly more laborious. Commercially available benzoyl acetonitrile (15) was treated with a strong base to form the enolate, which was reacted with carbon disulfide. The resulting dithiocarboxylic acid anions were reacted with iodomethane to form ketene dithioacetal 16 . The following cyclization, using guanidine hydrochloride and an excess base, provided the cyanopyrimidine scaffold. ${ }^{23}$ Subsequent oxidation of the thioether gave sulfone 18 , which was subjected to a substitution-hydrolysis sequence using potassium thioacetate followed by a strong base. ${ }^{24}$ The resulting free thiol (19) was then alkylated using 7 to provide the final compound 3 with a yield of $46 \%$.

The synthetic routes toward the pyridine derivatives are shown in Scheme 2. The synthesis of compound $\mathbf{4}$ started with a Knoevenagel condensation between acetophenone and malononitrile. $^{25}$ The thus formed intermediate 21 was reacted with dimethyl cyanocarbonimidodithioate to establish the cyanopyridine core. ${ }^{26}$ Similar to the synthesis route of compound 3, treatment with meta-chloroperbenzoic acid (mCPBA) provided the sulfone (23), which was converted to free thiol 24. Alkylation of the free thiol using 7 gave the final compound 4. Similar to the synthesis of compound 2, the synthesis of compound $\mathbf{5}$ started from a triple-halogensubstituted heteroaromatic system. Commercially available 
Scheme 1. Synthesis Route toward Pyrimidine and Triazine Derivatives $1-3^{a}$

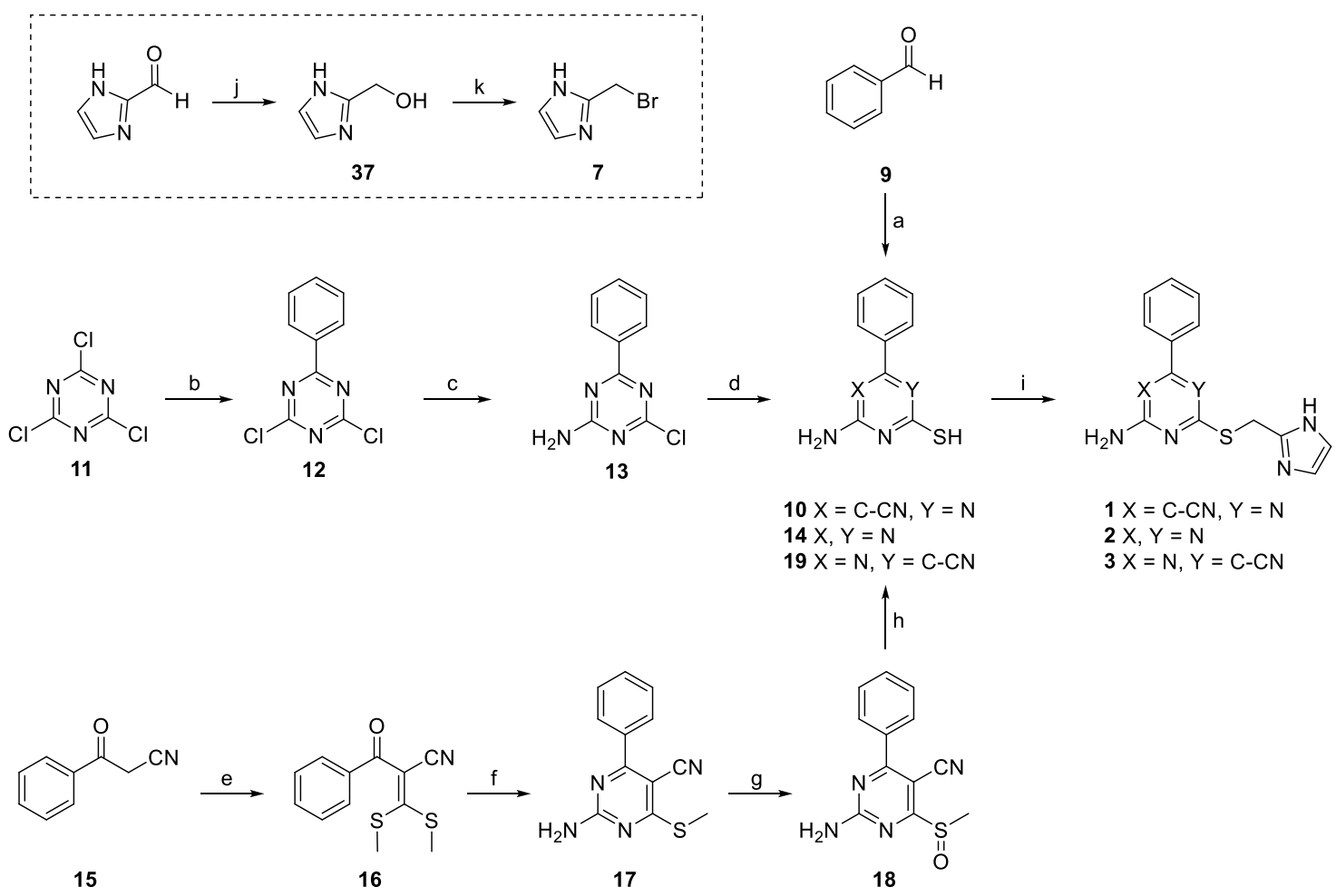

${ }^{a}$ Reagents and conditions: (a) malononitrile, thiourea, $\mathrm{K}_{2} \mathrm{CO}_{3}$, EtOH, reflux, 21\% (for 10); (b) R-phenylmagnesium bromide, dry THF, $\mathrm{N}_{2}$, rt, $52 \%$; (c) $\mathrm{NH}_{3}$ (25\%) in $\mathrm{H}_{2} \mathrm{O}, \mathrm{CH}_{2} \mathrm{Cl}_{2}, \mathrm{rt}, 66 \%$; (d) $\mathrm{Na}_{2} \mathrm{~S} \cdot 9 \mathrm{H}_{2} \mathrm{O}$, DMF, $80{ }^{\circ} \mathrm{C}, 28 \%$ (for 14); (e) $\mathrm{NaH}$, carbon disulfide, iodomethane, dry DMSO, $\mathrm{N}_{2}$, rt, 82\%; (f) guanidine hydrochloride, TEA, DMF, reflux, 42\%; (g) mCPBA, $\mathrm{CH}_{2} \mathrm{Cl}_{2}, \mathrm{rt}, 66 \%$; (h) potassium thioacetate, DMF, rt, $53 \%$ (for 19); (i) 7, $\mathrm{Na}_{2} \mathrm{CO}_{3}, \mathrm{DMF}, \mathrm{rt}, 3-46 \%$; (j) $\mathrm{NaBH}_{4}$, absolute $\mathrm{EtOH}, \mathrm{rt}, 75 \%$; (k) $33 \% \mathrm{HBr}$ in $\mathrm{CH}_{3} \mathrm{COOH}$, reflux, $65 \%$.

2,6-dichloro-4-iodopyridine (25) was selectively alkylated on the 4-position using a Suzuki cross-coupling reaction to give intermediate 26 in quantitative yield. ${ }^{27}$ Subsequent sequential nucleophilic aromatic substitution of the two chloro-groups using equimolar tert-butylthiol and tert-butyl carbamate, respectively, gave intermediate $\mathbf{2 8}^{28,29}$ Treatment with trifluoroacetic acid (TFA), followed by treatment with conc. $\mathrm{HCl}$, yielded the deprotected intermediate 30 in two steps. It was later found that this deprotection sequence could also be performed in one step by directly using hydrochloric acid. The final compound $\mathbf{5}$ was obtained in a yield of $33 \%$ by alkylation of 30 with 7 using the same procedure as mentioned before. Last, toward compound 6, commercially available ethylbenzoyl acetate (31) was reacted with 2-cyanoacetamide to give the cyanopyridine intermediate 32 , which was subjected to double chlorination using phosphorus oxychloride to yield the asymmetric cyanopyridine dichloride $33^{30,31}$ In an initial attempt to directly substitute one of the chlorides, tertbutylthiol was added to intermediate 33 . However, even after varying the reaction temperature and substitution on the thiol, inseparable mixtures of 2-(tert-alkylthio)-6-chloro-substituted (desired compound), 6-(tert-alkylthio)-2-chloro-substituted, and disubstituted 2,6-bis(tert-alkylthio)-4-phenylnicotinonitrile were obtained. Instead, Buchwald-Hartwig amination using tert-butyl carbamate was attempted. Gratifyingly, using this procedure, intermediate $\mathbf{3 4}$ was obtained with the correct substitution and as a single product. Subsequent addition of tert-butylthiol followed by one-step deprotection of both protective groups using hydrochloric acid gave intermediate 36, which was alkylated using the procedure mentioned previously to produce the final compound 6 in $8 \%$ yield.
Pharmacological Assessment of the Library of Compound 8 Derivatives. We first assessed the compounds' affinities for all adenosine receptor subtypes in radiolabeled antagonist ${ }^{10}$ binding studies on cell membranes expressing the individual receptors $\left(\mathrm{A}_{1}:\left[{ }^{3} \mathrm{H}\right] \mathrm{DPCPX} ; \mathrm{A}_{2 \mathrm{~A}}:\left[{ }^{3} \mathrm{H}\right] \mathrm{ZM} 241385\right.$; $A_{2 B}:\left[{ }^{3} \mathrm{H}\right]$ PSB-603; $A_{3}$ : $\left[{ }^{3} \mathrm{H}\right]$ PSB-11). Single-point displacement assays at $1 \mu \mathrm{M}$ on all four human adenosine receptor subtypes were performed as a preliminary assay for all compounds. Only compounds that showed greater than $50 \%$ radioligand displacement were evaluated in full-range concentration-dependent displacement assays to determine their affinities (Table 1 and Figure S4).

Of all compounds tested, the parent compound $\mathbf{8}$ displayed the highest affinity toward all human adenosine receptor subtypes, being slightly selective for the $\mathrm{hA}_{1} \mathrm{AR}$ with a $K_{\mathrm{i}}$ value of $3 \mathrm{nM}$. Modification of $\mathbf{8}$ by changing one cyano group at the thiol side for a nitrogen atom in the pyridine core yielded compound 1 with a significant, 10-30 fold, decreased affinity toward all adenosine receptor subtypes. Changing the other cyano group in $\mathbf{8}$ in the same way at the other, "left-hand" side provided compound 3 with similar affinity to 8 on hA ${ }_{2 A} \mathrm{AR}\left(K_{\mathrm{i}}\right.$ $=10 \mathrm{nM})$, while it showed approximately 25 -fold lower affinity at $h A_{1} A R$ and $h A_{3} A R$, rendering this compound the more selective derivative at $\mathrm{hA}_{2 \mathrm{~A}} \mathrm{R}$. The non-nitrile triazine compound $\mathbf{2}$ displayed lower affinity at all adenosine receptor subtypes with minimal affinity toward $\mathrm{hA}_{2 \mathrm{~B}} \mathrm{AR}$ (only $2 \%$ displacement of radioligand binding). The mono-cyano pyridine derivative $\mathbf{4}$ with structural resemblance to 1 displayed lower affinity than 1 on all adenosine receptor subtypes except $\mathrm{hA}_{2 \mathrm{~B}} \mathrm{AR}$, where it had a $K_{\mathrm{i}}$ value of $370 \mathrm{nM}$, rendering it the more nonselective derivative over all four adenosine receptor 
Scheme 2. Synthesis Route toward Pyridine Derivatives $4-6^{25 a}$

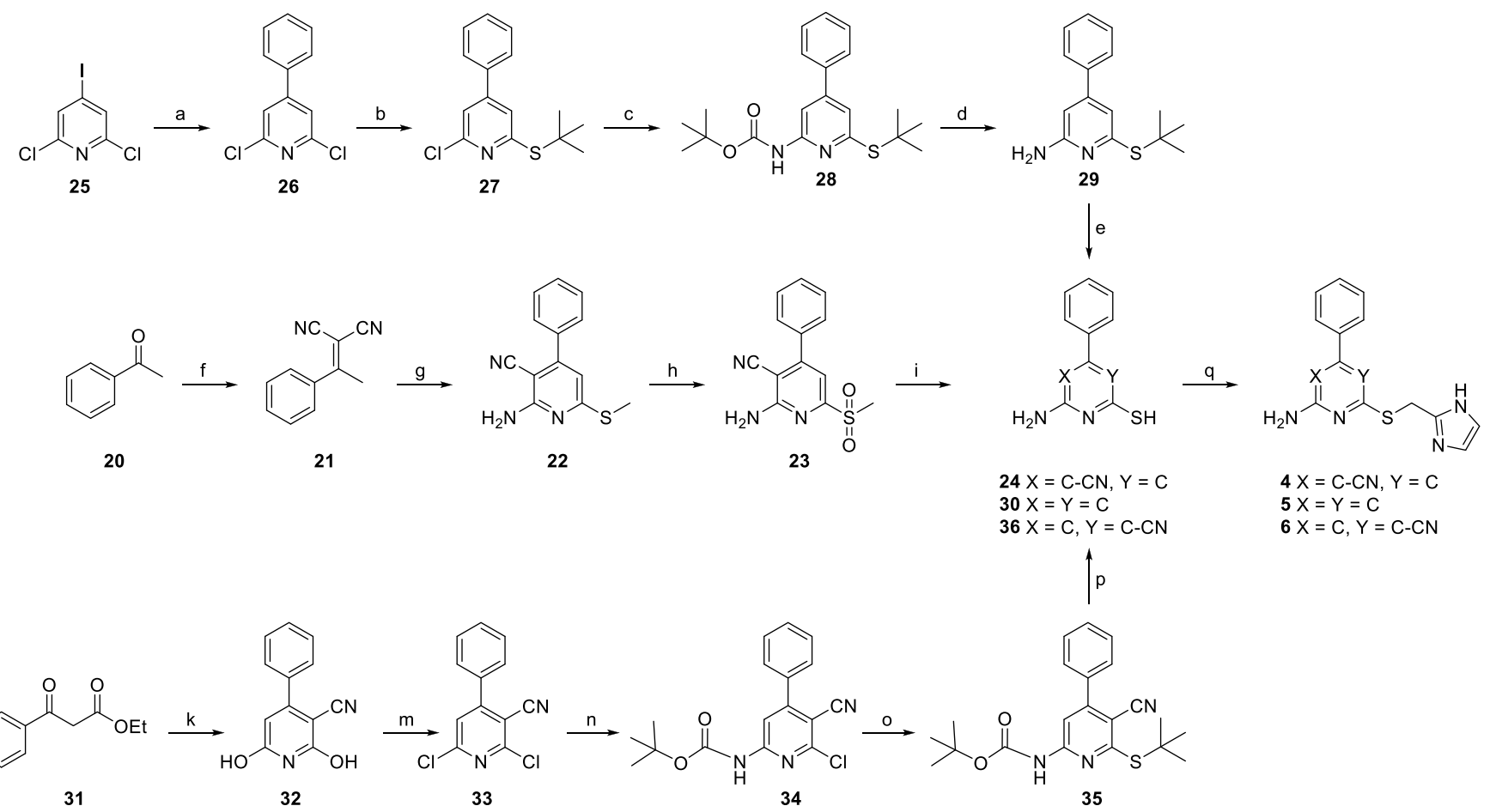

${ }^{a}$ Reagents and conditions: (a) phenylboronic acid pinacol esther, $\mathrm{Pd}\left(\mathrm{PPh}_{3}\right) \mathrm{Cl}_{2}, \mathrm{Na}_{2} \mathrm{CO}_{3}, \mathrm{H}_{2} \mathrm{O} / \mathrm{MeCN}, \mathrm{N}_{2}, 70{ }^{\circ} \mathrm{C}, 92 \%$; (b) 2-methylpropanethiol, $\mathrm{Cs}_{2} \mathrm{CO}_{3}$, DMF, $80{ }^{\circ} \mathrm{C}$, quantitative yield; (c) $\mathrm{Pd}(\mathrm{OAc})_{2}$, Xantphos, $\mathrm{Cs}_{2} \mathrm{CO}_{3}$, t-butyl carbamate, dry 1,4 -dioxane, $\mathrm{N}_{2}, 110{ }^{\circ} \mathrm{C}, 27 \%$; (d) TFA, $\mathrm{CH}_{2} \mathrm{Cl}_{2}$, reflux, $75 \%$; (e) $37 \% \mathrm{HCl}, 100{ }^{\circ} \mathrm{C}$; (f) malononitrile, ammonium acetate, toluene, reflux in Dean-Stark apparatus, $70 \%$; $(\mathrm{g})(\mathrm{i})$ dimethyl cyanocarbonimidodithioate, $\mathrm{K}_{2} \mathrm{CO}_{3}$, DMF, rt, (ii) piperidine, $80{ }^{\circ} \mathrm{C}, 62 \%$; (h) $\mathrm{mCPBA}, \mathrm{CH}_{2} \mathrm{Cl}_{2}, \mathrm{rt}, 56 \%$; (i) potassium thioacetate, DMF, rt, 61\% (for 24); (k) 2-cyanoacetamide, $\mathrm{KOH}, \mathrm{EtOH}$, reflux, 34\%; (m) $\mathrm{POCl}_{3}$ in an autoclave, $180{ }^{\circ} \mathrm{C}, 70 \%$; (n) $\mathrm{Pd}(\mathrm{OAc})_{2}, \mathrm{Xantphos}_{2} \mathrm{Cs}_{2} \mathrm{CO}_{3}, t$ butyl carbamate, dry 1,4-dioxane, $\mathrm{N}_{2}, 40{ }^{\circ} \mathrm{C}$, 33\%; (o) 2-methyl-propanethiol, $\mathrm{Cs}_{2} \mathrm{CO}_{3}, \mathrm{DMF}, 90{ }^{\circ} \mathrm{C}, 89 \%$; (p) $37 \% \mathrm{HCl}, 100{ }^{\circ} \mathrm{C}, 37 \%$ (for 36); (q) $7, \mathrm{NaHCO}_{3}, \mathrm{DMF}, \mathrm{rt}, 8-57 \%$.

Table 1. Affinities of 8 and Derivatives $(1-6)$ in Radioligand Binding Assays on the Human Adenosine Receptors

\begin{tabular}{ccclc} 
& \multicolumn{4}{c}{$\mathrm{p} K_{\mathrm{i}}$ or \% displacement ${ }^{a}$} \\
\cline { 2 - 5 } compound & \multicolumn{1}{c}{$\mathrm{A}_{1} \mathrm{AR}^{b}$} & \multicolumn{1}{c}{$\mathrm{A}_{2 \mathrm{~A}} \mathrm{AR}^{c}$} & \multicolumn{1}{c}{$\mathrm{A}_{2 \mathrm{~B}} \mathrm{AR}^{d}$} & $\mathrm{~A}_{3} \mathrm{AR}^{e}$ \\
$\mathbf{8}$ & $8.52 \pm 0.04$ & $8.13 \pm 0.05$ & $7.40 \pm 0.05$ & $7.38 \pm 0.01$ \\
$\mathbf{1}$ & $7.07 \pm 0.01$ & $7.17 \pm 0.08$ & $51 \%^{f}$ & $6.46 \pm 0.06$ \\
$\mathbf{2}$ & $6.54 \pm 0.05$ & $6.25 \pm 0.08$ & $2 \%^{f}$ & $5.42 \pm 0.06$ \\
$\mathbf{3}$ & $7.16 \pm 0.02$ & $8.00 \pm 0.05$ & $50 \%^{f}$ & $5.94 \pm 0.05$ \\
$\mathbf{4}$ & $6.38 \pm 0.06$ & $6.42 \pm 0.01$ & $6.43 \pm 0.03$ & $5.57 \pm 0.05$ \\
$\mathbf{5}$ & $12 \%^{g}$ & $-17 \%^{g}$ & $-12 \%^{f}$ & $46 \%^{g}$ \\
$\mathbf{6}$ & $6.95 \pm 0.08$ & $5.99 \pm 0.12$ & $37 \%^{f}$ & $5.87 \pm 0.10$
\end{tabular}

${ }^{a}$ Data are expressed as mean \pm SEM of three separate experiments each performed in duplicate, unless indicated otherwise. ${ }^{b}$ Displacement of $\left[{ }^{3} \mathrm{H}\right] \mathrm{DPCPX}$ binding in $\mathrm{CHO}$ cells expressing $\mathrm{hA} \mathrm{A}_{1} \mathrm{AR}$. ${ }^{c}$ Displacement of $\left[{ }^{3} \mathrm{H}\right] \mathrm{ZM} 241385$ binding in HEK293 cells expressing $\mathrm{hA}_{2 \mathrm{~A}} \mathrm{AR}$. ${ }^{d}$ Displacement of $\left[{ }^{3} \mathrm{H}\right]$ PSB-603 binding in $\mathrm{CHO}$ cells expressing $\mathrm{hA}_{2 \mathrm{~B}} \mathrm{AR}$. ${ }^{e}$ Displacement of $\left[{ }^{3} \mathrm{H}\right] \mathrm{PSB}-11$ binding in $\mathrm{CHO}$ cells expressing $\mathrm{hA}_{3} \mathrm{AR}$. ${ }^{f}$ Percent displacement $(n=2)$ of specific $\left[{ }^{3} \mathrm{H}\right]$ PSB-603 binding in $\mathrm{CHO}$ cells expressing $\mathrm{hA}_{2 \mathrm{~B}} \mathrm{AR}$ at $1 \mu \mathrm{M}$ ligand concentrations. ${ }^{g}$ Percent displacement $(n=2)$ of specific radioligand binding at $10 \mu \mathrm{M}$ ligand concentrations.

subtypes. The mono-cyano pyridine derivative 6 with the same cyano position as in pyrimidine 3 showed a significant, 100fold lower affinity to $\mathrm{hA}_{2 \mathrm{~A}} \mathrm{AR}$ compared to 3, although it had similar affinity to the other subtypes. Pyridine 5, lacking both cyano groups, was almost devoid of affinity at all adenosine receptor subtypes, as it showed no or negligible displacement of radioligand binding in the preliminary single-concentration assays $(1 \mu \mathrm{M})$. Apparently, the number of nitrogen atoms in or around the scaffold is an important determinant of receptor binding, especially for $\mathrm{hA}_{2 \mathrm{~A}} \mathrm{AR}$.

Next, we examined the compounds' efficacy/intrinsic activity in a label-free impedance-based assay on cells expressing $\mathrm{hA}_{2 \mathrm{~A}} \mathrm{AR}$. As the parent compound 8 had been identified as a partial agonist, ${ }^{11,12}$ we sought to characterize the new derivatives for their functional behavior along the agonist/ antagonist spectrum. Intrinsic activities of $\mathbf{8}$ and its derivatives at $\mathrm{hA}_{2 \mathrm{~A}} \mathrm{AR}$ were assessed using a label-free whole-cell assay with a real-time cell analysis (RTCA) system by measuring the flow of electrons transmitted between two gold electrodes at the bottom of a well in a 96-well plate. Upon receptor activation, the HEK293hA ${ }_{2 A} \mathrm{R}$ cell morphology changes and covers more of the electrodes, which impedes the electron flow. The impedance produced is displayed as a unit-less number, the so-called cell index $(\mathrm{CI}) .^{32} \mathrm{~A}$ reference full agonist of $\mathrm{hA}_{2 \mathrm{~A}} \mathrm{AR}$, ribose-containing CGS21680, was used to define the highest $\mathrm{CI}$ observed, and the peak values obtained were used to determine $\mathrm{EC}_{50}$ values. Concentration-response curves of CGS21680 and the compounds in the library are displayed in Figure 3. In this study, the parent compound 8 showed a lower potency than CGS21680 and acted as a partial agonist of the receptor, with an intrinsic activity $\left(E_{\max }\right.$ value) of $66 \pm 5 \%$ (Table 2). A similar observation had been reported in a previous study by Beukers et al., ${ }^{11}$ focusing on cAMP production as a signaling readout. 


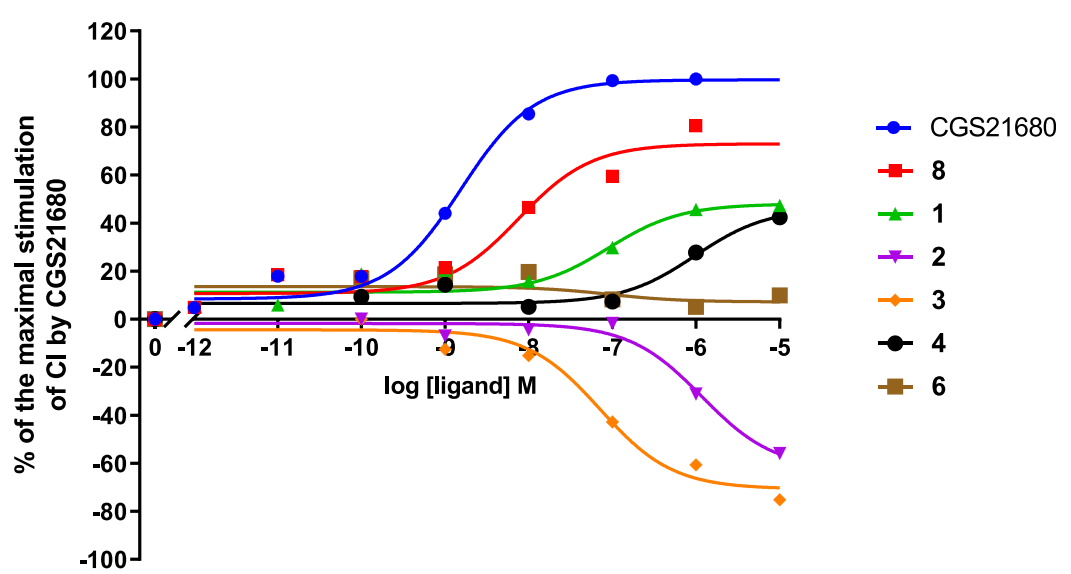

Figure 3. Concentration-response curves for CGS21680 and nonriboside compounds at HEK293hA ${ }_{2 A} \mathrm{R}$ derived from the peak analysis of cell index (CI) changes obtained in the xCELLigence RTCA system. The cellular responses were normalized and shown as \% of the maximal CI by 1 $\mu \mathrm{M}$ CGS21680. Representative graphs from one experiment performed in duplicate.

Table 2. Compound Potency and Intrinsic Activity Derived from the Label-Free Whole-Cell Assay Performed on HEK293-hA ${ }_{2 \mathrm{~A}} \mathrm{R}^{\mathrm{Cells}}{ }^{a}$

compound
CGS21680
$\mathbf{1}$
2
3
4
6

$\mathrm{pEC}_{50}$
$8.85 \pm 0.08$
$8.01 \pm 0.22$
$6.57 \pm 0.37$
$6.09 \pm 0.23$
$7.35 \pm 0.28$
$5.78 \pm 0.38$
N.D.

$E_{\max } \%$
$100 \pm 2$
$66 \pm 5$
$41 \pm 5$
$-48 \pm 5$
$-50 \pm 5$
$37 \pm 7$
N.D.

${ }^{a}$ Data are shown as mean \pm S.E.M. of three independent experiments performed in duplicate. Log potency $\left(\mathrm{pEC}_{50}\right)$ and efficacy $\left(E_{\max }\right)$ were calculated from concentration-response curves derived from the peak analysis of CI changes. N.D., not determined.

Various responses were shown by the nonriboside derivatives. The pyrimidine compound $\mathbf{1}$ behaved as a partial agonist as well $\left(E_{\max }=41 \pm 5 \%\right)$, although it had lower potency than $8\left(\mathrm{pEC}_{50}\right.$ of $6.57 \pm 0.37$ vs $\left.8.01 \pm 0.22\right)$. The pyridine derivative 4 was a partial agonist too $\left(E_{\max }=37 \pm\right.$ $7 \%)$ but with the lowest measurable potency in the series $\left(\mathrm{pEC}_{50}=5.78 \pm 0.38\right)$. Remarkably, compound 3 , the derivative with the highest selectivity for $\mathrm{hA}_{2 \mathrm{~A}} \mathrm{AR}$, had an opposite activity compared to 8 . Figure 3 shows that this cyanopyrimidine compound acted as an inverse agonist at the receptor $\left(E_{\max }=-50 \pm 5 \%\right)$ with a potency quite comparable to $8\left(\mathrm{pEC}_{50}=7.35 \pm 0.28\right)$. The absence of both cyano groups in the triazine compound $\mathbf{2}$ also led to inverse agonism at $\mathrm{hA}_{2 \mathrm{~A}} \mathrm{AR}$ with similar efficacy $(-48 \pm 5 \%)$ to 3 , albeit with significantly lower potency $\left(\mathrm{pEC}_{50}=6.09 \pm 0.23\right.$ vs $7.35 \pm$ 0.28 ). Compound 6 did not show any measurable degree of intrinsic activity, as it neither activated nor inactivated the receptor (Figure 3). These results show that modification/ deletion of the cyano groups alters the functional characteristics of the compounds. Keeping the cyano group at the amino, "left-hand" side maintained agonism, while the absence of this group abolished this feature, resulting in inverse agonism for $\mathbf{2}$ and $\mathbf{3}$ and, possibly, neutral antagonism for $\mathbf{6}$.

Molecular Modeling. Intrigued by the findings in the pharmacological experiments, we decided to perform inducedfit docking studies of compounds $\mathbf{1}$ and 3, the two compounds with the most obvious differences in receptor activation patterns while having appreciable affinity for the adenosine $A_{2 A}$ receptor. To prepare the receptor structure for this analysis, the bRIL fusion partner was removed from the crystal structure and the third intracellular loop (ICL3) was implemented again. ${ }^{33}$ Mutated amino acids used to thermostabilize the structure in the crystallization process, such as M1P, A54L, T88A, R107A, K122A, N154A, L235A, and V239A, were changed back to the wild-type amino acids. Missing water molecules were retrieved from a previous high-resolution crystal structure (PDB ID: 4EIY) ${ }^{2}$ to provide stability of the receptor-ligand interaction in the docking simulation. First, as a control experiment, compound $\mathbf{8}$ was docked into this wildtype $\mathrm{hA}_{2 \mathrm{~A}} \mathrm{AR}$ model. Induced flexible docking allowed the imidazole moiety to adopt slightly different positions, not surprisingly in view of its orientation toward the more flexible extracellular loops. The dicyanopyridine scaffold, however, did hardly move (Figure S5). Next, compounds 1 and 3 were flexibly docked ${ }^{34}$ into the binding pocket with the binding pose of 8 as a reference (Figures 4-6, respectively). The partial agonist $\mathbf{1}$ showed a similar binding pose as $\mathbf{8}$ after convergence of the docking procedure, with two hydrogen bonds with Asn $253^{6.55}$, one hydrogen bond with Glu169 ${ }^{\mathrm{ECL} 2}$, a $\pi-\pi$ stacking interaction with Phe $168^{5.29}$, and its phenyl moiety surrounded by Ser277.42 and His $278^{7.43}$ (Figures 4 and 6). The inverse agonist 3 took a slightly different pose due to the absence of the cyano substituent on the "left-hand" side of the molecule. The ligand moved closer to Asn253 $3^{6.55}$ as to maintain hydrogen bonding, now to the nitrogen atom in the ligand's core. As a result, it also forms two hydrogen bonds with Asn $253^{6.55}$, one hydrogen bond with Glu $169^{\mathrm{ECL2}}$, and a $\pi-\pi$ stacking interaction between its pyrimidine core and Phe $168^{5.29}$. However, this movement also caused a shift of the phenyl moiety away from Ser $277^{7.42}$ and His $278^{7.43}$, bringing this moiety closer to His $250^{6.52}$ (Figures 5 and 6). A similar alignment is also present in the binding pocket of antagonist/ inverse agonist ZM241385. Its furan ring forms a $\pi-\pi$ stacking interaction with His250 $0^{6.52}$ (Figure S2A).

\section{DISCUSSION AND CONCLUSIONS}

The ligand binding pocket of $\mathbf{8}$ encompasses amino acids that have been subjected to a mutagenesis study by Lane et al. in which the reference agonist CGS21680 and LUF5834 (Figure 1 ), a close analogue of $\mathbf{8}$, were compared. ${ }^{16}$ In fact, within the scope of the present study, we also attempted to obtain a 


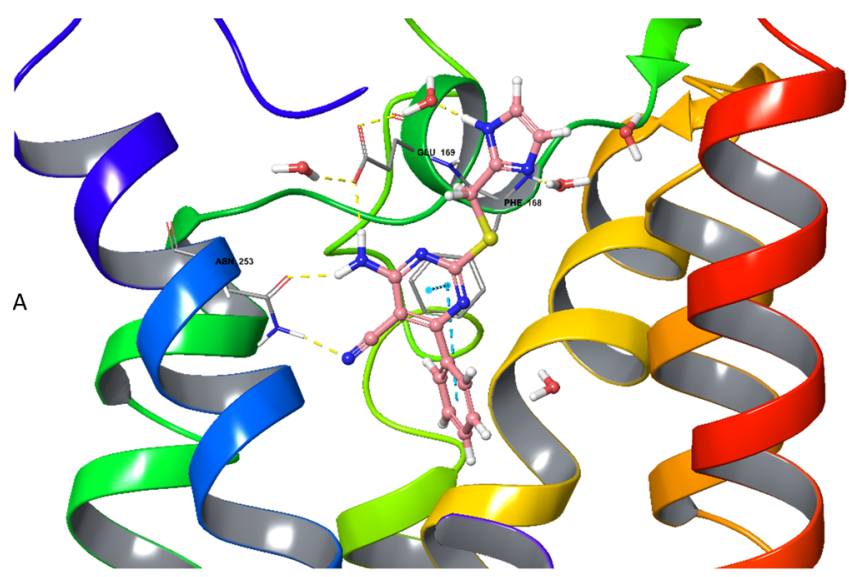

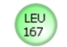<smiles>[CH]</smiles>

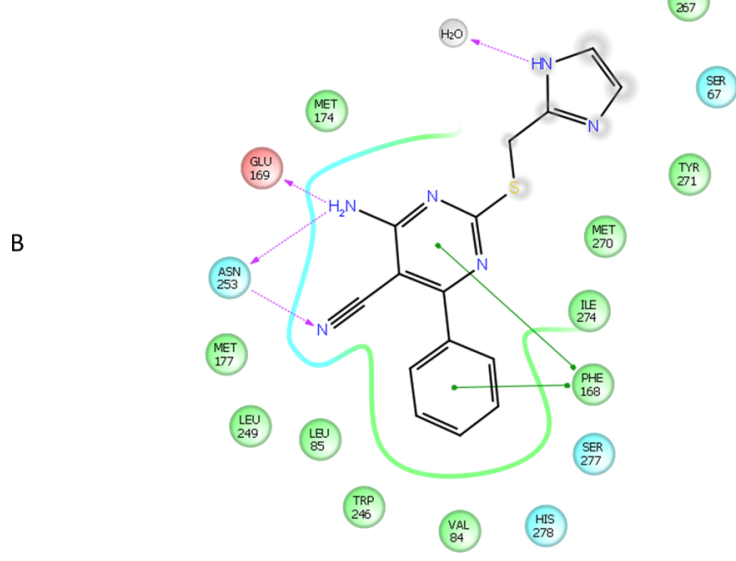

Figure 4. (A) Proposed binding mode of compound 1 in the $h A_{2 A} A R$ crystal structure with all nine thermostabilizing mutations reverted to wild-type $\mathrm{hA}_{2 \mathrm{~A}} \mathrm{AR}$, obtained by induced-fit docking. It shows the interactions formed between 1 and the receptor, in particular three hydrogen bond interactions with Asn253 $3^{6.55}$ and Glu169 $9^{5.30}$, and two $\pi-\pi$ stacking interactions with Phe $168^{5.29}$. A part of helix 7 was omitted for better visualization. (B) Two-dimensional representation of the interaction between $\mathbf{1}$ and $\mathrm{hA}_{2 \mathrm{~A}} \mathrm{AR}$ in the ligand binding cavity within a $4 \AA$ distance (green circle: hydrophobic; red circle: negatively charged; blue circle: polar; gray circle: water; gradient gray circle: solvent exposed). The phenyl moiety is surrounded by Ser $277^{7.42}$ and His $278^{7.43}$, key residues in receptor activation.

receptor crystal structure with LUF5834 but were unsuccessful. The authors performed cAMP measurements to demonstrate that the potencies of both CGS21680 and LUF5834 were dramatically ( $>100$-fold) reduced in the Phe $168^{5.29}$ alanine mutant, in accordance with the pivotal role this amino acid plays in coordinating the scaffold and phenyl substituent of $\mathbf{8}$ in the crystal structure. The Asn $253^{6.55}$ alanine mutation negatively affected CGS2160 potency and LUF5834 intrinsic activity, with the latter losing its partial agonist activity and turning into an antagonist. The Ala mutant of Glu169 ${ }^{\mathrm{EL} 2}$ on the contrary slightly increased the potency and intrinsic activity of LUF5834 with no effect on CGS21680. This amino acid has been shown to interact with a histidine (His264 ${ }^{6.66}$ ) residue to form a lid above the binding pocket of the receptor, affecting the residence time of AR ligands. ${ }^{13}$ Alanine mutation of Ser $277^{7.42}$, as present in the crystal structure, reduced the potency of CGS21680 by two orders of magnitude, while

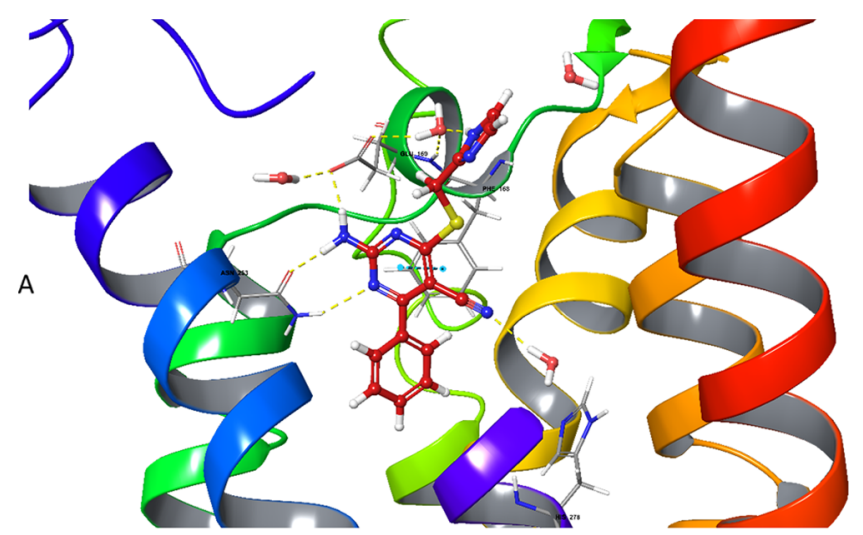

$\left(\begin{array}{ccc}\text { LEV } \\ 167\end{array}\right.$

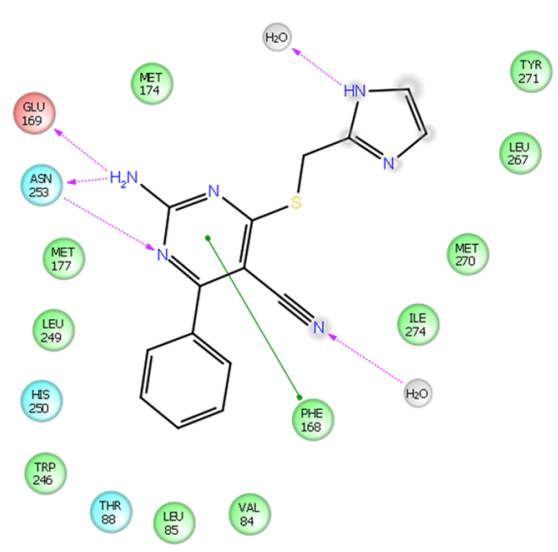

Figure 5. (A) Proposed binding mode of compound 3 in the $h A_{2 A} A R$ crystal structure with all nine thermostabilizing mutations reverted to wild-type $\mathrm{hA}_{2 \mathrm{~A}} \mathrm{AR}$, obtained by induced-fit docking. Compared to Figure 4 (compound 1), the hydrogen bond interaction between the nitrogen atom in the pyrimidine ring and Asn $253^{6.55}$ causes a shift of 3 's position in the binding cavity. A part of helix 7 was omitted for better visualization. (B) Two-dimensional representation of the interaction between 3 and $\mathrm{hA}_{2 \mathrm{~A}} \mathrm{AR}$ in the ligand binding cavity within a $4 \AA$ distance (green circle: hydrophobic; red circle: negatively charged; blue circle: polar; gray circle: water; gradient gray circle: solvent exposed). Most key interactions for binding to the receptor are maintained, but the phenyl moiety is moved away from Ser $277^{7.42}$ and His $278^{7.43}$.

LUF5834's potency and affinity increased somewhat and the compound turned into a full agonist.

Rather than reiterating this mutagenesis study to include $\mathbf{8}$, we decided to synthesize and test six derivatives of the compound for a further analysis of its agonistic characteristics. The decoration of the scaffold was altered in a one-by-one step fashion to compare the effect of relatively minor changes on both potency and intrinsic activity. These structural alterations caused changes in affinity, as assessed on all four adenosine receptor subtypes through radioligand binding studies. All compounds were less active than $\mathbf{8}$, in particular compound 5, bearing the pyridine scaffold without cyano substituents. Interestingly, compound 3 was the most selective for $\mathrm{hA}_{2 \mathrm{~A}} \mathrm{AR}$; it kept its affinity on this receptor subtype, while its affinity for the other adenosine receptor subtypes dropped substantially (Table 1 ).

We then examined the functional characteristics of the compounds in label-free functional experiments on intact HEK293 cells overexpressing $\mathrm{hA}_{2 \mathrm{~A}} \mathrm{AR}$. We had reported 


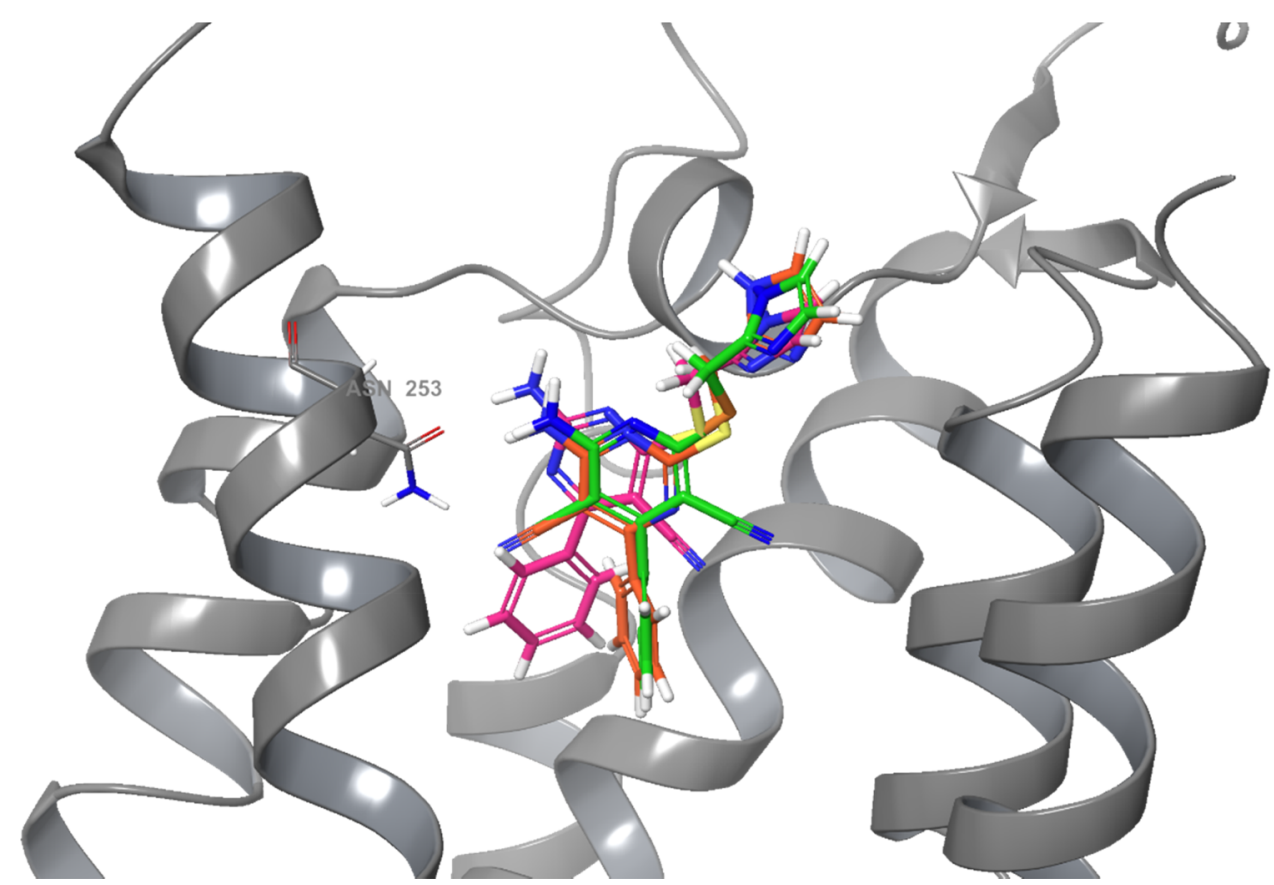

Figure 6. Superimposition of compounds $\mathbf{1}$ (orange), $\mathbf{3}$ (pink), and $\mathbf{8}$ (green) in the $\mathrm{hA}_{2 \mathrm{~A}} \mathrm{AR}$ crystal structure with all nine thermostabilizing mutations reverted to wild-type $\mathrm{hA}_{2 \mathrm{~A}} \mathrm{AR}$, obtained by induced-fit docking. For reasons of clarity, only five helices and the amino acid Asn $253^{6.55}$ are shown.

previously that the endogenous expression of $h A_{2 B} A R$ on these cells does not compromise the functional evaluation of $\mathrm{hA}_{2 \mathrm{~A}} \mathrm{AR}$ occupancy. ${ }^{16}$ Hence, we were able to record the $\mathrm{pEC}_{50}$ values of all compounds in this cell system (Table 2 and Figure 4) and compared these with the radioligand binding data. The $\mathrm{p} K_{\mathrm{i}}$ and $\mathrm{pEC}_{50}$ values were strongly correlated $\left(r^{2}=0.91, P=0.01\right.$, Figure S6) yet another indication of the unequivocal involvement of $\mathrm{hA}_{2 \mathrm{~A}} \mathrm{AR}$. It also suggests there is no or negligible receptor reserve, in line with the partial nature of the compounds' efficacy.

We were quite surprised to record huge changes in intrinsic activity. Here, some of the compounds ( 2 and $\mathbf{3}$ ) were turned into inverse agonists instead of (partial) agonists. Only compounds 1 and 4, both retaining the cyano substituent on the "left-hand" side of the molecule, kept the partial agonist profile as in 8. Induced-fit docking studies helped interpret our pharmacological findings. Subtle ligand movements in the binding pocket carried some ligands away from "agonistic" amino acids to negate their activation potential, while other ligands kept a partial agonistic profile. These ligand movements may also be dependent on the presence of explicit water molecules. In the $\mathrm{hA}_{2 \mathrm{~A}} \mathrm{AR}-\mathrm{ZM} 241385$ crystal structure, three water molecules occupy a region next to the furan ring of $\mathrm{ZM} 241385,{ }^{2,3}$ which is taken by the riboside moiety in an $\mathrm{hA}_{2 \mathrm{~A}} \mathrm{AR}$-agonist structure. ${ }^{35}$ It is entirely plausible that $\mathbf{8}$ and derivatives take intermediate positions with varying amounts of water molecules, reflecting their antagonistic vs agonistic nature. In a previous study focusing on the $h A_{1} A R$, we had synthesized a series of quite different monocyanopyrimidines but also with the cyano substituent on either the "left hand" or "right hand" side of the scaffold. ${ }^{36}$ These compounds were all inverse agonists, however, suggesting that depending on the hAR subtype, subtle changes at various parts of these molecules can alter the activation profile dramatically and differently.
In conclusion, in this study, we elucidated the structure of the adenosine $A_{2 A}$ receptor bound to a chemically distinct partial agonist, compound $\mathbf{8}$. The interaction profile between the ligand and the receptor included amino acids that had been shown to be involved in receptor activation in earlier, e.g., mutagenesis studies. The synthesis and molecular docking of a series of derivatives of the partial agonist allowed us to further investigate the requirements for receptor activation. With this newly solved structure, we significantly expand the repertoire of $\mathrm{A}_{2 \mathrm{~A}}$ receptor structures, allowing a more elaborate analysis of the ligand binding pocket than in any other GPCR.

\section{EXPERIMENTAL SECTION}

Crystal Structure Determination. $A_{2 A}$-Star2 bRIL Construct. The $\mathrm{A}_{2 \mathrm{~A}}-\mathrm{StaR} 2$ construct consists of nine thermostabilizing mutations: A54L $\mathrm{L}^{2.52}, \mathrm{~T} 88 \mathrm{~A}^{3.36}, \mathrm{R} 107 \mathrm{~A}^{3.55}, \mathrm{~K} 122 \mathrm{~A}^{4.43}, \mathrm{~N} 154 \mathrm{~A}$, L202A $A^{5.63}$, L235A $A^{6.37}, \mathrm{~V} 239 \mathrm{~A}^{6.41}$, and S277 $\mathrm{A}^{7.42}$. The first three amino acids at the $\mathrm{N}$-terminus were deleted and the protein had a C-terminal truncation after L 315 where 3 additional alanines and 10 histidines were added. The apocytochrome b 562 RIL (bRIL) was inserted into the third intracellular loop (ICL3) between residues L208 and G218.

Expression. The $\mathrm{A}_{2 \mathrm{~A}}$-StaR2-bRIL was expressed using the baculovirus system. Tni PRO cells were grown in suspension in flasks up to a maximum volume of $500 \mathrm{~mL}$ in $2 \mathrm{~L}$ roller bottles at 27 ${ }^{\circ} \mathrm{C}$ with shaking. Cells were grown in ESF921 (Expression Systems) medium supplemented with 5\% (v/v) FBS and $1 \%(\mathrm{v} / \mathrm{v})$ penicillin/ streptomycin. Cells were infected at a density of $2.6 \times 10^{6}$ cells $/ \mathrm{mL}$ with recombinant virus at an approximate multiplicity of infection of 1. Cells were harvested by centrifugation $48 \mathrm{~h}$ post infection.

Membranes were prepared from a pellet of $2 \mathrm{~L}$ cells resuspended in $40 \mathrm{mM}$ Tris- $\mathrm{HCl}$ ( $\mathrm{pH}$ 7.6), $1 \mathrm{mM}$ EDTA, and Complete EDTA-free protease inhibitor cocktail tablets (Roche). Cells were disrupted through a microfluidizer (processor M-110L Pneumatic, Microfluidics) cooled down with ice (lysis pressure, $\sim 15,000 \mathrm{psi}$ ) and membranes were pelleted by centrifugation at $200,000 \mathrm{~g}$ for $50 \mathrm{~min}$. Membranes were washed with $40 \mathrm{mM}$ Tris- $\mathrm{HCl}$ ( $\mathrm{pH}$ 7.6), $1 \mathrm{M}$ $\mathrm{NaCl}$, and Complete EDTA-free protease inhibitor cocktail tablets 
and centrifuged at $200,000 \mathrm{~g}$ for $50 \mathrm{~min}$. After removal of the supernatant, membranes were resuspended in $50 \mathrm{~mL}$ with $40 \mathrm{mM}$ Tris- $\mathrm{HCl}(\mathrm{pH} 7.6)$ and Complete EDTA-free protease inhibitor cocktail tablets and frozen at $-80{ }^{\circ} \mathrm{C}$.

Purification and Lipidic Cubic Phase Crystallization. Cells from 2 $\mathrm{L}$ cultures were resuspended and disrupted using a microfluidizer (Processor M-110L Pneumatic, Microfluidics). Membranes pelleted by ultracentrifugation were subjected to a high-salt wash in a buffer containing $1 \mathrm{M} \mathrm{NaCl}$ before being resuspended in $50 \mathrm{~mL}$ of $40 \mathrm{mM}$ Tris ( $\mathrm{pH}$ 7.6) supplemented with Complete EDTA-free protease inhibitor cocktail tablets and stored at $-80{ }^{\circ} \mathrm{C}$ until further use. Membranes were thawed, resuspended in a total volume of $150 \mathrm{~mL}$, and incubated with $3 \mathrm{mM}$ theophylline (Sigma-Aldrich) for $2 \mathrm{~h}$ at room temperature. Membranes were then solubilized by addition of $1.5 \% n$-decyl- $\beta$-D-maltopyranoside (DM, Anatrace) and incubation for $2 \mathrm{~h}$ at $4{ }^{\circ} \mathrm{C}$, followed by centrifugation at $145000 \mathrm{~g}$ for $60 \mathrm{~min}$ to harvest a solubilized material. The solubilized material was applied to a $5 \mathrm{~mL}$ Ni-NTA (nickel-nitrilotriacetic acid) Superflow cartridge (Qiagen) and the protein was eluted with a buffer containing $1 \mathrm{mM}$ theophylline. Collected fractions were pooled, concentrated, and applied to a Superdex200 size exclusion column (GE Healthcare). Fractions containing the protein were then concentrated to $\sim 35 \mathrm{mg} /$ $\mathrm{mL}$ and subjected to an ultracentrifugation at $436,000 \mathrm{~g}$ prior to crystallization. Protein concentrations were measured using the detergent compatible (DC) protein assay (Bio-Rad).

The $A_{2 A}$-StaR2-bRIL was crystallized first in complex with theophylline in the lipidic cubic phase at $20^{\circ} \mathrm{C}$. The final protein/ lipid ratio was 40:60 (w/w), and $40 \mathrm{~nL}$ of boli was dispensed using a Mosquito LCP crystallization robot (TTP Labtech) and overlaid with $800 \mathrm{~nL}$ of precipitant solution. Crystals grew within 2 weeks in $0.1 \mathrm{M}$ trisodium citrate ( $\mathrm{pH} 5.3-5.4$ ), $0.05 \mathrm{M}$ sodium thiocyanate, $29-32 \%$ PEG400, 2\% (v/v) 2,5-hexanediol, and $0.5 \mathrm{mM}$ theophylline. Then, incisions were made into the Laminex cover over base wells containing crystals, and wells were flooded with $10 \mu \mathrm{L}$ of mother liquor supplemented by compound $8(1 \mathrm{mM})$. Flooded wells were then resealed and plates were incubated for $24 \mathrm{~h}$ at $20{ }^{\circ} \mathrm{C}$. Single crystals were mounted in LithoLoops (Molecular Dimensions Ltd.) and flash-frozen in liquid nitrogen without the addition of further cryoprotectant.

Data Collection and Structure Solution. X-ray diffraction data $\left(0.25^{\circ} /\right.$ frame; $\sim 500$ frames $)$ were collected on an Eiger $16 \mathrm{M}$ detector at beamline X06SA (Swiss Light Source) in a single swipe from one crystal. Integration was carried out using $\mathrm{XDS}^{37}$ and scaled using aP scale $^{38}$ (Global Phasing, Cambridge, U.K.). The structure of the $\mathrm{A}_{2 \mathrm{~A}^{-}}$ StaR2-bRIL complex with compound $\mathbf{8}$ was solved by molecular replacement (MR) with Phaser ${ }^{39}$ within the CCP4 interface using the previously reported $A_{2 A}$-StaR2-bRIL-theophylline complex structure as the search model (PDB code: 5MZJ). Model refinement was performed initially using phenix.refine ${ }^{40}$ and then using BUSTER ${ }^{41}$ (Global Phasing), including TLS refinement for two groups corresponding to the receptor and bRIL562, respectively. The crystallographic data reduction and refinement statistics are presented in Table 3.

Chemistry. All solvents and reagents were of analytical grade and purchased from commercial sources. Demineralized water was simply referred to as $\mathrm{H}_{2} \mathrm{O}$ and used in all cases, unless stated otherwise (i.e., brine). Thin-layer chromatography (TLC), aluminum-coated Merck silica gel F254 plates were used to monitor the progression of the reactions. The ${ }^{1} \mathrm{H}$ NMR spectra were recorded on a Bruker AV400 liquid spectrometer $\left({ }^{1} \mathrm{H} \mathrm{NMR}, 400 \mathrm{MHz} ;{ }^{13} \mathrm{C} \mathrm{NMR}, 100 \mathrm{MHz}\right)$ at ambient temperature. Chemical shifts are reported in parts per million (ppm), designated by $\delta$ and downfield to the internal standard tetramethylsilane (TMS) in $\mathrm{CDCl}_{3}$. Coupling constants are reported in $\mathrm{Hz}$ and designated as $J$. The analytical purity of the final compounds was determined by high-performance liquid chromatography (HPLC) with a Phenomenex Gemini $3 \mu \mathrm{m} \mathrm{C18} 110 \AA$ A column $(50 \times 4.6 \mathrm{~mm}, 3 \mu \mathrm{m})$, measuring UV absorbance at $254 \mathrm{~nm}$. Sample preparation and HPLC method were as follows: $0.3-1.0 \mathrm{mg}$ of compound was dissolved in $1 \mathrm{~mL}$ of a 1:1:1 mixture of $\mathrm{MeCN} / \mathrm{H}_{2} \mathrm{O}$ / $t \mathrm{BuOH}$ and eluted from the column within $15 \mathrm{~min}$ at a flow rate of

Table 3. Data Collection and Refinement Statistics

$\mathrm{A}_{2 \mathrm{~A}}$-LUF5833 (compound 8)

data collection

number of crystals

space group

cell dimensions

$a, b, c(\AA)$

$\alpha, \beta, \gamma\left({ }^{\circ}\right)$

resolution $(\AA)$

no. of reflections

$R_{\text {pim }}$

$I / \sigma(I)$

$\mathrm{CC}_{1 / 2}$

completeness (\%)

spherical

ellipsoidal

redundancy

1

$39.54,181.03,140.85$

90, 90,90

$43.09-3.12(3.31-3.12)^{a}$

$7990(399)^{a}$

$0.134(0.934)^{a}$

$5.2(1.1)^{a}$

$0.992(0.309)^{a}$

$84.5(26.3)^{a}$

$87.2(32.5)^{a}$

$3.9(4.0)^{a}$

refinement

\begin{tabular}{|c|c|}
\hline resolution $(\AA)$ & $43.09-3.12$ \\
\hline $\begin{array}{l}R_{\text {work }} / R_{\text {free }} \\
\text { no. of atoms }\end{array}$ & $0.223 / 0.254$ \\
\hline protein & 2937 \\
\hline ligand & 24 \\
\hline other & 69 \\
\hline \multicolumn{2}{|l|}{$B$ factors } \\
\hline protein & 77.21 \\
\hline ligand & 62.56 \\
\hline other & 67.69 \\
\hline \multicolumn{2}{|l|}{ r.m.s. deviations } \\
\hline bond lengths $(\AA)$ & 0.007 \\
\hline bond angles $\left({ }^{\circ}\right)$ & 0.81 \\
\hline
\end{tabular}

${ }^{a}$ Values in parentheses are for the highest-resolution shell.

$1.3 \mathrm{~mL} / \mathrm{min}$ with a three-component system of $\mathrm{H}_{2} \mathrm{O} / \mathrm{MeCN} / 1 \% \mathrm{TFA}$ in $\mathrm{H}_{2} \mathrm{O}$. The elution method was set up as follows: in a 1-4 min isocratic system of $\mathrm{H}_{2} \mathrm{O} / \mathrm{MeCN} / 1 \%$ TFA in $\mathrm{H}_{2} \mathrm{O}, 80: 10: 10$, from the 4th min, a gradient was applied from 80:10:10 to 0:90:10 within 9 min, followed by $1 \mathrm{~min}$ of equilibration at 0:90:10 and $1 \mathrm{~min}$ at 80:10:10. All final compounds showed a single peak at the designated retention time and were thus considered at least $95 \%$ pure. Liquid chromatography-mass spectrometry (LC-MS) analyses were performed on a Thermo Finnigan Surveyor-LCQ Advantage Max LC-MS system, Shimadzu LCMS-2020 system, and Phenomenex Gemini C18 110A columns $(50 \times 4.6 \mathrm{~mm}, 3 \mu \mathrm{m}$; $50 \times 3 \mathrm{~mm}, 3 \mu \mathrm{m})$. The sample preparation was the same as for HPLC analysis. The compounds were eluted from the column within 15 min after injection, with a three-component system of $\mathrm{H}_{2} \mathrm{O} / \mathrm{MeCN}+0.1 \% \mathrm{FA}$, while decreasing the polarity of the solvent mixture in time from 90:10 to 10:90. Purification by column chromatography was achieved by use of Grace Davison Davisil silica column material (LC60A 30200 micron). Solutions were concentrated using a Heidolph Laborota W8 2000 efficient rotary evaporation apparatus. All reactions in the synthetic routes were performed without a nitrogen atmosphere, unless stated otherwise.

(1H-Imidazol-2-yl)methanol (37). ${ }^{11}$ To a suspension of $\mathrm{NaBH}_{4}$ $(0.787 \mathrm{~g}, 20.8 \mathrm{mmol}, 2.0$ equiv) in absolute $\mathrm{EtOH}(15 \mathrm{~mL})$ was added commercially available $1 \mathrm{H}$-imidazole-2-carbaldehyde $(1 \mathrm{~g}, 10.4 \mathrm{mmol}$, 1.0 equiv) portion-wise. The mixture was stirred at room temperature for $3 \mathrm{~h}$. After the completion of the reaction, the mixture was quenched with water and concentrated in vacuo. The crude compound was purified by flash column chromatography $(10 \%$ $\mathrm{MeOH}$ in $\mathrm{CHCl}_{3}$ ) to obtain 37 as a pale yellow solid $(769 \mathrm{mg}, 7.85$ mmol, 75\%). ${ }^{1} \mathrm{H}$ NMR (400 MHz, MeOD): $\delta 6.97$ (s, 2H, imidazoyl), $4.61\left(\mathrm{~s}, 2 \mathrm{H}, \mathrm{CH}_{2}\right)$. 
2-(Bromomethyl)-1H-imidazole hydrobromide (7). ${ }^{11}$ A suspension of $37(0.55 \mathrm{~g}, 5.6 \mathrm{mmol})$ in $\mathrm{HBr} 33 \%$ (w/v) acetic acid solution $(10 \mathrm{~mL})$ was heated at $100^{\circ} \mathrm{C}$ for $5 \mathrm{~h}$. The mixture was concentrated in vacuo and treated with $25 \%$ PET in diethyl ether. The suspended solid was collected by filtration and dried to give 7 as a pale brown solid (885 mg, $3.66 \mathrm{mmol}, 65 \%) .{ }^{1} \mathrm{H}$ NMR (400 MHz, MeOD): $\delta$ $7.60\left(\mathrm{~s}, 2 \mathrm{H}\right.$, imidazolyl), $4.82\left(\mathrm{~s}, 2 \mathrm{H}, \mathrm{CH}_{2}\right)$. HNMR is consistent with the reported literature data.

4-Amino-2-sulfanyl-6-phenylpyrimidine-5-carbonitrile (10). ${ }^{20}$ To malononitrile $(0.99 \mathrm{~g}, 15 \mathrm{mmol}, 1.0$ equiv) dissolved in ethanol $(7.5 \mathrm{~mL})$ were added benzaldehyde $(1.528 \mathrm{~mL}, 15 \mathrm{mmol}, 1.0$ equiv), thiourea ( $1.14 \mathrm{~g}, 15 \mathrm{mmol}, 1.0$ equiv), and $\mathrm{K}_{2} \mathrm{CO}_{3}(2.07 \mathrm{~g}, 15 \mathrm{mmol}$, 1.0 equiv). The mixture was stirred at reflux for $5 \mathrm{~h}$. Upon the completion of the reaction, the precipitate formed in the mixture was filtered and then stirred with warm water $\left(50{ }^{\circ} \mathrm{C}\right)$. The filtrate was acidified with acetic acid to $\mathrm{pH}$ below 7 . The precipitate formed was filtrated and dried in vacuo to obtain $\mathbf{1 0}$ as a white solid $(716 \mathrm{mg}, 3.14$ mmol, 21\%). ${ }^{1} \mathrm{H}$ NMR (400 MHz, DMSO): $\delta 13.07$ (br s, $1 \mathrm{H}, \mathrm{SH}$ ), 8.45 (br s, $1 \mathrm{H}, 0.5 \mathrm{NH}_{2}$ ), 7.93 (br s, $1 \mathrm{H}, 0.5 \mathrm{NH}_{2}$ ), 7.68 (d, $J=6.8$ $\mathrm{Hz}, 2 \mathrm{H}, \mathrm{Ph}), 7.63-7.53(\mathrm{~m}, 3 \mathrm{H}, \mathrm{Ph})$.

2-(1H-Imidazol-2-yl)methylthio-4-amino-6-phenylpyrimidine-5carbonitrile (1). Alkylation was performed according to previously reported procedures. ${ }^{11}$ To a solution of free thiol $10(0.684 \mathrm{~g}, 3$ mmol, 1.0 equiv) in DMF $(12 \mathrm{~mL})$ were added 2-bromomethylimidazole 7 ( $0.483 \mathrm{~g}, 3 \mathrm{mmol}, 1.0$ equiv) and $\mathrm{Na}_{2} \mathrm{CO}_{3}(0.318 \mathrm{~g}, 3 \mathrm{mmol}$, 1.0 equiv). The reaction was stirred at $50{ }^{\circ} \mathrm{C}$ for $4 \mathrm{~h}$. Water $(60 \mathrm{~mL})$ was added to force the crude product to precipitate, which was collected by filtration. The precipitate was washed with DMF $(6 \mathrm{~mL})$ and EtOAc $(6 \mathrm{~mL})$, and water $(30 \mathrm{~mL})$ was added to cause precipitation, which was filtered and dried in vacuo to obtain the desired product as a white powder (370 $\mathrm{mg} ; 1.20 \mathrm{mmol}$; yield, $40 \%)$. Mp $237^{\circ} \mathrm{C} .{ }^{1} \mathrm{H}$ NMR ( $850 \mathrm{MHz}, \mathrm{DMSO}$ ): $\delta 11.85$ (br s, $1 \mathrm{H}, \mathrm{NH}$ ), 8.30 (br s, $1 \mathrm{H}$, imidazolyl), 7.86-7.84 (m, $2 \mathrm{H}, \mathrm{Ph}), 7.80($ br s, $1 \mathrm{H}$, imidazolyl), $7.58(\mathrm{tt}, J=7.6,1.7 \mathrm{~Hz}, 1 \mathrm{H}, \mathrm{Ph}), 7.54(\mathrm{tt}, J=6.8,1.7 \mathrm{~Hz}$, $2 \mathrm{H}, \mathrm{Ph}), 7.10-6.80\left(\mathrm{~m}, 2 \mathrm{H}, \mathrm{NH}_{2}\right), 4.43\left(\mathrm{~s}, 2 \mathrm{H}, \mathrm{CH}_{2}\right) . \mathrm{MS}$ (ESI): calcd for $\mathrm{C}_{15} \mathrm{H}_{12} \mathrm{~N}_{6} \mathrm{~S}[\mathrm{M}+\mathrm{H}]^{+}, 309.08$; found: 309.00. HPLC: 3.107 min; purity: $99 \%$.

2,4-Dichloro-6-phenyl-1,3,5-triazine (12). ${ }^{42}$ To a stirred suspension of commercially available cyanuric chloride $11(0.5 \mathrm{~g}, 2.71 \mathrm{mmol}$, 1.0 equiv $)$ in dry $\mathrm{THF}(20 \mathrm{~mL})$ at $0{ }^{\circ} \mathrm{C}$ under a nitrogen atmosphere was added a $3 \mathrm{M}$ solution of phenylmagnesium bromide $(0.993 \mathrm{~mL}$, $2.98 \mathrm{mmol}, 1.1$ equiv) in THF $(10 \mathrm{~mL})$ dropwise (over $30 \mathrm{~min})$. The reaction mixture was stirred at room temperature for $6 \mathrm{~h}$. Upon the completion of the reaction (monitored by TLC), the mixture was treated with $10 \%$ aqueous $\mathrm{HCl}(50 \mathrm{~mL})$ and extracted with EtOAc $(40 \mathrm{~mL} \times 3)$. The combined organic layer was washed with water $(30$ $\mathrm{mL}$ ), dried on $\mathrm{MgSO}_{4}$, and evaporated under reduced pressure to give the intermediate as a brown solid $(318 \mathrm{mg}, 1.42 \mathrm{mmol}, 52 \%)$. The crude product was used for the next reaction without further purification. ${ }^{1} \mathrm{H}$ NMR $\left(400 \mathrm{MHz}, \mathrm{CDCl}_{3}\right) \delta 8.50(\mathrm{dd}, J=8.0,1.6 \mathrm{~Hz}$, $2 \mathrm{H}, \mathrm{Ph}), 7.66(\mathrm{tt}, J=7.6,1.2 \mathrm{~Hz}, 1 \mathrm{H}, \mathrm{Ph}), 7.54(\mathrm{t}, J=8.0 \mathrm{~Hz}, 2 \mathrm{H}$, $\mathrm{Ph})$.

4-Chloro-6-phenyl-1,3,5-triazine-2-amine (13). ${ }^{43}$ Aqueous ammonia (25\%) was added dropwise $(0.1 \mathrm{~mL}, 1.327 \mathrm{mmol}, 1.0$ equiv) to a stirred solution of $12\left(0.3 \mathrm{~g}, 1.327 \mathrm{mmol}, 1.0\right.$ equiv) in $\mathrm{CH}_{2} \mathrm{Cl}_{2}$ (5 $\mathrm{mL}$ ). The resulting mixture was stirred at room temperature for $8 \mathrm{~h}$. The reaction progress was monitored by TLC. The precipitate formed was filtered, rinsed with $\mathrm{CH}_{2} \mathrm{Cl}_{2}(30 \mathrm{~mL})$, and dried under reduced pressure, affording a pale orange solid of $13(180 \mathrm{mg}, 0.87 \mathrm{mmol}$, $66 \%)$. The compound was used in the next reaction without further purification. ${ }^{1} \mathrm{H}$ NMR $\left(400 \mathrm{MHz}, \mathrm{CDCl}_{3}\right) \delta 8.40(\mathrm{~d}, J=8.0,1.6 \mathrm{~Hz}$, $2 \mathrm{H}, \mathrm{Ph}), 7.57(\mathrm{tt}, J=7.6,1.6 \mathrm{~Hz}, 1 \mathrm{H}, \mathrm{Ph}), 7.51(\mathrm{t}, J=8.0 \mathrm{~Hz}, 2 \mathrm{H}$, $\mathrm{Ph}$ ), 5.71 (br s, $2 \mathrm{H}, \mathrm{NH}_{2}$ ). MS (ESI) calcd for $\mathrm{C}_{9} \mathrm{H}_{7} \mathrm{ClN}_{4}[\mathrm{M}+\mathrm{H}]^{+}$: 207.04; found, 207.10.

4-Amino-6-phenyl-1,3,5-triazine-2-thiol (14). ${ }^{44}$ A suspension of 13 (0.68 g, $3.29 \mathrm{mmol}, 1.0$ equiv) and sodium sulfide nonahydrate $\left(1.185 \mathrm{~g}, 4.93 \mathrm{mmol}, 1.5\right.$ equiv) in DMF $(3 \mathrm{~mL})$ was stirred at $80^{\circ} \mathrm{C}$ for $3 \mathrm{~h}$. The reaction progress was monitored by TLC. DMF was evaporated under reduced pressure at $80{ }^{\circ} \mathrm{C}$. The resulting residue was treated carefully with $\mathrm{HCl}$ in EtOAc $(10 \mathrm{~mL})$. The suspended solid was collected by filtration and extracted with boiling EtOH (20 $\mathrm{mL} \times 5)$. The collected organic layers were concentrated in vacuo and washed with warm DCM $(15 \mathrm{~mL} \times 3)$ to afford a pale yellow solid (190 mg, $0.92 \mathrm{mmol}, 28 \%) .{ }^{1} \mathrm{H}$ NMR (400 MHz, DMSO) $\delta 12.84$ (br s, $1 \mathrm{H}, \mathrm{SH}), 8.22$ (d, $J=7.6 \mathrm{~Hz}, 2 \mathrm{H}, \mathrm{Ph}), 8.20$ (br s, $1 \mathrm{H}, 0.5 \mathrm{NH}_{2}$ ), $7.77\left(\right.$ br s, $\left.1 \mathrm{H}, 0.5 \mathrm{NH}_{2}\right), 7.59(\mathrm{t}, J=7.6 \mathrm{~Hz}, 1 \mathrm{H}, \mathrm{Ph}), 7.51(\mathrm{t}, J=8.0$ $\mathrm{Hz}, 2 \mathrm{H}, \mathrm{Ph}$ ). MS (ESI) calcd for $\mathrm{C}_{9} \mathrm{H}_{8} \mathrm{~N}_{4} \mathrm{~S}[\mathrm{M}+\mathrm{H}]^{+}$, 205.05; found, 205.10.

4-(1H-Imidazol-2-yl)methylthio-6-phenyl-1,3,5-triazin-2-amine (2). Similar procedure as synthesis of 1 using $14(0.148 \mathrm{~g}, 0.725$ mmol, 1.0 equiv) as a starting material. The final compound 2 was obtained as a white solid ( $7 \mathrm{mg}$; $0.02 \mathrm{mmol}$; yield, 3\%). Mp $209^{\circ} \mathrm{C}$. ${ }^{1} \mathrm{H}$ NMR (400 MHz, MeOD): $\delta 8.34(\mathrm{dd}, J=8.4,1.2 \mathrm{~Hz}, 2 \mathrm{H}, \mathrm{Ph})$, $7.53(\mathrm{tt}, J=7.6,1.2 \mathrm{~Hz}, 1 \mathrm{H}, \mathrm{Ph}), 7.45(\mathrm{t}, J=7.6 \mathrm{~Hz}, 2 \mathrm{H}, \mathrm{Ph}), 6.97(\mathrm{br}$ s, $2 \mathrm{H}$, imidazolyl), 4.49 (s, $2 \mathrm{H}, \mathrm{CH}_{2}$ ). MS (ESI): calcd for $\mathrm{C}_{13} \mathrm{H}_{12} \mathrm{~N}_{6} \mathrm{~S}$ $[\mathrm{M}+\mathrm{H}]^{+}, 285.08$; found, 285.00. HPLC: $6.906 \mathrm{~min}$; purity, $98 \%$.

2-Benzoyl-3,3-bis(methylthio)acrylonitrile (16). ${ }^{45} \mathrm{~A}$ solution of benzoylacetonitrile 15 (1.189 g, $8.2 \mathrm{mmol}, 1.0$ equiv) in $16 \mathrm{~mL}$ of dry DMSO was added dropwise to a stirred suspension of $60 \% \mathrm{NaH}$ dispersion in mineral oil ( $0.656 \mathrm{~g}, 16.4 \mathrm{mmol}, 2.0$ equiv) in $16 \mathrm{~mL}$ of dry DMSO under the $\mathrm{N}_{2}$ condition at room temperature. Carbon disulfide ( $0.49 \mathrm{~mL}, 8.2 \mathrm{mmol}, 1.0$ equiv) was added dropwise under external water bath cooling, and the mixture was stirred for $2 \mathrm{~h}$. Iodomethane ( $1.0 \mathrm{~mL}, 16.4 \mathrm{mmol}, 2.0$ equiv) was then added to the mixture dropwise under external water bath cooling, and the reaction was stirred overnight. The reaction progress was monitored by TLC. After the completion of the reaction, the mixture was poured into 600 $\mathrm{mL}$ of ice-cold water, and the precipitate formed was filtered and dried in vacuo to provide 16 in good yield $(1.677 \mathrm{~g}, 6.72 \mathrm{mmol}, 82 \%)$. ${ }^{1} \mathrm{H}$ NMR (400 MHz, DMSO) $\delta 7.85(\mathrm{~d}, J=7.2 \mathrm{~Hz}, 2 \mathrm{H}, \mathrm{Ph}), 7.67(\mathrm{t}$, $J=7.6 \mathrm{~Hz}, 1 \mathrm{H}, \mathrm{Ph}), 7.55(\mathrm{t}, J=7.6 \mathrm{~Hz}, 2 \mathrm{H}, \mathrm{Ph}), 2.80\left(\mathrm{~s}, 3 \mathrm{H}, \mathrm{CH}_{3}\right)$, $2.53\left(\mathrm{~s}, 3 \mathrm{H}, \mathrm{CH}_{3}\right)$.

2-Amino-4-(methylthio)-6-phenylpyrimidine-5-carbonitrile (17) ${ }^{46}$ A solution of $16(0.168 \mathrm{~g}, 6.73 \mathrm{mmol}, 1.0$ equiv), guanidine hydrochloride $(0.643 \mathrm{~g}, 6.73 \mathrm{mmol}, 1.0$ equiv), and triethylamine (2.34 mL, $16.8 \mathrm{mmol}, 2.5$ equiv) in $21 \mathrm{~mL}$ of DMF was heated at reflux for $6 \mathrm{~h}$. The reaction progress was monitored by TLC. After the completion of the reaction, the mixture was cooled down to room temperature and $32 \mathrm{~mL}$ of water was added to cause precipitation. The precipitate was collected by filtration and washed with water and methanol to give compound $\mathbf{1 7}$ as a pale yellow solid $(680 \mathrm{mg}, 2.83$ mmol, 42\%). ${ }^{1} \mathrm{H}$ NMR (400 MHz, DMSO) $\delta 7.88$ (br s, $1 \mathrm{H}, 0.5$ $\mathrm{NH}_{2}$ ), 7.81 (br s, $1 \mathrm{H}, 0.5 \mathrm{NH}_{2}$ ) 7.80-7.78 (m, $\left.2 \mathrm{H}, \mathrm{Ph}\right), 7.57-7.51$ $(\mathrm{m}, 3 \mathrm{H}, \mathrm{Ph}), 2.58\left(\mathrm{~s}, 3 \mathrm{H}, \mathrm{CH}_{3}\right)$.

2-Amino-4-(methylsulfinyl)-6-phenylpyrimidine-5-carbonitrile (18). ${ }^{46}$ Intermediate $17(0.706 \mathrm{~g}, 2.92 \mathrm{mmol}, 1.0$ equiv) was dissolved in $10 \mathrm{~mL}$ of $\mathrm{CH}_{2} \mathrm{Cl}_{2}$ at room temperature, and mCPBA (0.808 g, 4.68 mmol, 1.6 equiv) was added to the mixture. The mixture was stirred at room temperature for $3.5 \mathrm{~h}$ and monitored by TLC. The precipitate formed in the reaction was filtered, washed by $\mathrm{CH}_{2} \mathrm{Cl}_{2}$, and dried under reduced pressure to obtain 18 (495 mg, $1.93 \mathrm{mmol}, 66 \%) .{ }^{1} \mathrm{H}$ NMR (400 MHz, DMSO) $\delta 8.39$ (br s, $1 \mathrm{H}, 0.5 \mathrm{NH}_{2}$ ), 8.32 (br s, $1 \mathrm{H}$, $0.5 \mathrm{NH}_{2}$ ), $7.84(\mathrm{~d}, J=7.2 \mathrm{~Hz}, 2 \mathrm{H}, \mathrm{Ph}), 7.64-7.54(\mathrm{~m}, 3 \mathrm{H}, \mathrm{Ph}), 2.93$ $\left(\mathrm{s}, 3 \mathrm{H}, \mathrm{CH}_{3}\right)$.

2-Amino-4-sulfanyl-6-phenylpirimidine-5-carbonitrile (19). ${ }^{47}$ To a stirred suspension of 18 (0.495 g, $1.92 \mathrm{mmol}, 1.0$ equiv) in $17 \mathrm{~mL}$ of DMF was added potassium thioacetate $(0.376 \mathrm{~g}, 3.84 \mathrm{mmol}, 2.0$ equiv), and the mixture was stirred at room temperature for $19 \mathrm{~h}$. The reaction progress was monitored by TLC. After the completion of the reaction, the mixture was cooled down in an external ice water bath, and $17 \mathrm{~mL}$ of $2 \mathrm{M}$ aqueous $\mathrm{NaOH}$ was added to the cold solution. The mixture was stirred for another $1.5 \mathrm{~h}$ and diluted with $17 \mathrm{~mL}$ of $\mathrm{H}_{2} \mathrm{O}$, followed by $\mathrm{pH}$ adjustment to 5-6 with the addition of $1 \mathrm{M}$ $\mathrm{HCl}( \pm 50 \mathrm{~mL})$. The mixture was diluted with $70 \mathrm{~mL}$ of $\mathrm{H}_{2} \mathrm{O}$ and stirred for $1 \mathrm{~h}$ at room temperature. The precipitate formed in the mixture was collected by filtration, washed with $\mathrm{H}_{2} \mathrm{O}(25 \mathrm{~mL} \times 3)$, and dried under reduced pressure to give 19 in good yield $(232 \mathrm{mg}$, $1.02 \mathrm{mmol}, 53 \%) .{ }^{1} \mathrm{H}$ NMR (400 MHz, DMSO) $\delta 12.91$ (br s, $1 \mathrm{H}$, $\mathrm{SH}), 8.67\left(\right.$ br s, $\left.1 \mathrm{H}, 0.5 \mathrm{NH}_{2}\right), 7.78(\mathrm{~d}, J=7.6 \mathrm{~Hz}, 2 \mathrm{H}, \mathrm{Ph}), 7.61-$ $7.48(\mathrm{~m}, 3 \mathrm{H}, \mathrm{Ph}), 6.95$ (br s, $\left.1 \mathrm{H}, 0.5 \mathrm{NH}_{2}\right)$. 
4-((1H-Imidazol-2-yl)methylthio)-2-amino-6-phenylpyrimidine5-carbonitrile (3). Similar procedure as synthesis of 1 using 19 (0.187 g, $0.82 \mathrm{mmol}, 1.0$ equiv) as a starting material to afford a light yellow solid (116 mg; $0.38 \mathrm{mmol}$; yield, $46 \%$ ). Mp $224{ }^{\circ} \mathrm{C}$. ${ }^{1} \mathrm{H}$ NMR (400 MHz, DMSO) $\delta 11.86($ br s, $1 \mathrm{H}, \mathrm{NH}), 7.97\left(\mathrm{~m}, 2 \mathrm{H}, \mathrm{NH}_{2}\right), 7.79$ (d, $J$ $=6.8 \mathrm{~Hz}, 2 \mathrm{H}, \mathrm{Ph}), 7.60-7.50(\mathrm{~m}, 3 \mathrm{H}, \mathrm{Ph}), 7.08(\mathrm{br} \mathrm{s}, 1 \mathrm{H}$, imidazolyl), 6.85 (br s, $1 \mathrm{H}$, imidazolyl), 4.53 (s, $2 \mathrm{H}, \mathrm{CH}_{2}$ ). MS (ESI): calcd for $\mathrm{C}_{15} \mathrm{H}_{12} \mathrm{~N}_{6} \mathrm{~S}[\mathrm{M}+\mathrm{H}]^{+}$, 309.08; found, 309.00. HPLC: 4.377 min; purity: $99 \%$.

2-(1-Phenylethylidene)malononitrile (21). ${ }^{25}$ The synthesis of this compound was adapted from the conditions previously described by Longstreet et al. ${ }^{25}$ A mixture of acetophenone $20(2.80 \mathrm{~mL}, 24 \mathrm{mmol}$, 1.0 equiv), malononitrile ( $1.586 \mathrm{~g}, 24.00 \mathrm{mmol}, 1$ equiv), and ammonium acetate $(0.370 \mathrm{~g}, 4.80 \mathrm{mmol}, 0.2$ equiv) in toluene (20 $\mathrm{mL}$ ) was heated at reflux under Dean-Stark conditions for $5 \mathrm{~h}$. The reaction progress was monitored by TLC. After the completion of the reaction, the mixture was cooled down to room temperature. The reaction was diluted with EtOAc $(50 \mathrm{~mL})$, washed with saturated $\mathrm{NaHCO}_{3}$ solution $(50 \mathrm{~mL} \times 3)$ followed by water $(50 \mathrm{~mL})$, dried over $\mathrm{MgSO}_{4}$, and concentrated in vacuo to obtain a brown oil, which solidified at room temperature after $30 \mathrm{~min}$. Purification was performed by column chromatography $\left(\mathrm{CH}_{2} \mathrm{Cl}_{2}\right)$ to obtain 21 as a white solid $(2.82 \mathrm{~g}, 16.8 \mathrm{mmol}, 70 \%) .{ }^{1} \mathrm{H} \mathrm{NMR}\left(400 \mathrm{MHz}, \mathrm{CDCl}_{3}\right) \delta$ 7.58-7.26 (m, 5H, Ph), $2.64\left(\mathrm{~s}, 3 \mathrm{H}, \mathrm{CH}_{3}\right)$. HNMR is consistent with the reported literature data.

2-Amino-6-(methylthio)-4-phenylnicotinonitrile (22). ${ }^{48} \mathrm{~A}$ mixture of 21 (2.5 g, $14.86 \mathrm{mmol}, 1.0$ equiv), dimethyl cyanocarbonimidodithioate (3.69 g, $25.3 \mathrm{mmol}, 1.7$ equiv), and potassium carbonate $(2.465 \mathrm{~g}, 17.84 \mathrm{mmol}, 1.2$ equiv) in DMF $(30 \mathrm{~mL})$ was stirred at room temperature for $6 \mathrm{~h}$. After the completion of the reaction, piperidine $(2.4 \mathrm{~mL}, 23.78 \mathrm{mmol}, 1.6$ equiv) was added and the mixture was stirred at $80{ }^{\circ} \mathrm{C}$ overnight. The reaction progress was monitored by TLC. The mixture was then concentrated in vacuo, diluted with water, and extracted three times with $\mathrm{CH}_{2} \mathrm{Cl}_{2}$. The organic layer was dried over $\mathrm{MgSO}_{4}$ and concentrated in vacuo. The brown oil obtained was purified by column chromatography $\left(\mathrm{CH}_{2} \mathrm{Cl}_{2}\right)$, yielding 22 as a yellow solid $(2.21 \mathrm{~g}, 9.21 \mathrm{mmol}, 62 \%)$. ${ }^{1} \mathrm{H}$ NMR (400 MHz, $\left.\mathrm{CDCl}_{3}\right) \delta 7.56-7.52(\mathrm{~m}, 2 \mathrm{H}, \mathrm{Ph}), 7.49-7.47$ (m, 3H, Ph), 6.64 (s, $1 \mathrm{H}$, pyridinyl), 5.27 (br s, $\left.2 \mathrm{H}, \mathrm{NH}_{2}\right), 2.54$ (s, $\left.3 \mathrm{H}, \mathrm{CH}_{3}\right)$.

2-Amino-6-(methylsulfonyl)-4-phenylnicotinonitrile (23). A mixture of 22 ( $1 \mathrm{~g}, 4.14 \mathrm{mmol}, 1$ equiv) and mCPBA (1.114 g, 4.97 mmol, 1 equiv) in $120 \mathrm{~mL}$ of $\mathrm{CH}_{2} \mathrm{Cl}_{2}$ was stirred at room temperature for 5 min. The mixture was then washed twice with $\mathrm{NaHCO}_{3}$ solution followed by water, dried over $\mathrm{MgSO}_{4}$, and concentrated in vacuo to yield a mixture of sulfoxide and sulfone product. Without further separation, it was then reacted with $77 \mathrm{wt} \%$ mCPBA (0.674 g, 3.90 mmol, 0.94 equiv) in $\mathrm{CH}_{2} \mathrm{Cl}_{2}(70 \mathrm{~mL})$ and stirred at room temperature for another $5 \mathrm{~min}$. The mixture was washed twice with $\mathrm{NaHCO}_{3}$ solution followed by water, dried over $\mathrm{MgSO}_{4}$, and concentrated in vacuo. Purification was performed by column chromatography $\left(2 \% \mathrm{MeOH}\right.$ in $\left.\mathrm{CH}_{2} \mathrm{Cl}_{2}\right)$, yielding 23 as a yellow solid $(0.631 \mathrm{~g}, 2.31 \mathrm{mmol}, 56 \%) .{ }^{1} \mathrm{H}$ NMR (400 MHz, DMSO) $\delta$ 7.68-7.65 (m, 4H, $\left.\mathrm{NH}_{2}+\mathrm{Ph}\right), 7.59-7.57(\mathrm{~m}, 3 \mathrm{H}, \mathrm{Ph}), 7.17(\mathrm{~s}, 1 \mathrm{H}$, pyridinyl), $3.27\left(\mathrm{~s}, 3 \mathrm{H}, \mathrm{CH}_{3}\right)$.

2-Amino-6-sulfanyl-4-phenylnicotinonitrile (24). A mixture of 23 $(0.631 \mathrm{~g}, 2.31 \mathrm{mmol}, 1$ equiv $)$ and potassium ethanethioate $(0.527 \mathrm{~g}$, $4.62 \mathrm{mmol}, 2$ equiv) in DMF $(8 \mathrm{~mL})$ was stirred at $80{ }^{\circ} \mathrm{C}$ for $4 \mathrm{~h}$. After the completion of the reaction as shown by TLC, $2 \mathrm{M} \mathrm{NaOH}$ solution was added and the mixture was stirred at room temperature for another $2 \mathrm{~h}$. The mixture was then diluted with water $(80 \mathrm{~mL})$ and $1 \mathrm{M} \mathrm{HCl}$ solution was added to adjust $\mathrm{pH}$ to 1 . The precipitate formed was filtered and dried in vacuo to obtain a brown crude solid. Purification was performed by column chromatography $(3 \% \mathrm{MeOH}$ in $\left.\mathrm{CH}_{2} \mathrm{Cl}_{2}\right)$ to obtain the product as a yellow solid $(0.321 \mathrm{~g}, 1.41$ mmol, $61 \%) .{ }^{1} \mathrm{H}$ NMR (400 MHz, DMSO) $\delta 12.58$ (s, $\left.1 \mathrm{H}, \mathrm{SH}\right)$, 7.58-7.48 (m, 6H), 7.31 (br s, $2 \mathrm{H}, \mathrm{NH}_{2}$ ), 6.47 (s, 1H). MS (ESI): calcd for $\mathrm{C}_{12} \mathrm{H}_{9} \mathrm{~N}_{3} \mathrm{~S}[\mathrm{M}+\mathrm{H}]^{+}$, 228.05; found, 228.13.

6-(((1H-Imidazol-2-yl)methyl)thio)-2-amino-4-phenylnicotinonitrile (4). A mixture of 24 (0.12 g, $0.66 \mathrm{mmol}, 1$ equiv), 7 ( $0.16 \mathrm{~g}, 0.66$ mmol, 1 equiv), and $\mathrm{NaHCO}_{3}$ (0.166 g, $1.98 \mathrm{mmol}, 2$ equiv) in DMF $(3 \mathrm{~mL})$ was stirred at $50{ }^{\circ} \mathrm{C}$ for $4 \mathrm{~h}$. After the completion of the reaction as shown by TLC, the mixture was concentrated in vacuo and dissolved in EtOAc followed by washing three times with water and brine. The organic phase was dried over $\mathrm{MgSO}_{4}$, concentrated in vacuo to give a crude yellow oil, and purified by dry-loaded column chromatography $\left(5 \% \mathrm{MeOH}\right.$ in $\mathrm{CH}_{2} \mathrm{Cl}_{2}$ ) as a column chromatography eluent. Compound 4 was obtained as a white solid (0.115 g; $0.376 \mathrm{mmol}$; yield, $57 \%) . \mathrm{Mp} 220{ }^{\circ} \mathrm{C} .{ }^{1} \mathrm{H}$ NMR (400 MHz, DMSO) $\delta 11.86($ br s, $1 \mathrm{H}, \mathrm{NH}), 7.587 .53(\mathrm{~m}, 2 \mathrm{H}, \mathrm{Ph}), 7.52-7.49(\mathrm{~m}, 3 \mathrm{H}$, $\mathrm{Ph}$ ), 7.17 (br s, $2 \mathrm{H}, \mathrm{NH}_{2}$ ), 7.05 (br s, $1 \mathrm{H}$, imidazolyl), 6.82 (br s, $1 \mathrm{H}$, imidazolyl), $6.68\left(\mathrm{~s}, 1 \mathrm{H}\right.$, pyridinyl), $4.39\left(\mathrm{~s}, 2 \mathrm{H}, \mathrm{CH}_{2}\right)$. MS (ESI): calcd for $\mathrm{C}_{16} \mathrm{H}_{13} \mathrm{~N}_{5} \mathrm{~S}[\mathrm{M}+\mathrm{H}]^{+}$, 308.09; found, 308.05. HPLC: 6.33 min; purity: $99 \%$.

2,6-Dichloro-4-phenylpyridine (26). ${ }^{49}$ A stirred suspension of 2,6dichloro-4-iodopyridine 25 ( $1 \mathrm{~g}, 3.65 \mathrm{mmol}, 1.0$ equiv), $\mathrm{Na}_{2} \mathrm{CO}_{3}$ $(1.16 \mathrm{~g}, 10.95 \mathrm{mmol}, 3.0$ equiv), phenylboronic acid pinacol ester (0.745 g, $3.65 \mathrm{mmol}, 1.0$ equiv), and $\mathrm{Pd}\left(\mathrm{PPh}_{3}\right)_{2} \mathrm{Cl}_{2}$ (0.128 g, 0.183 mmol, 0.05 equiv) in a mixture of acetonitrile $(12 \mathrm{~mL})$ and $\mathrm{H}_{2} \mathrm{O}(8$ $\mathrm{mL}$ ) under a $\mathrm{N}_{2}$ atmosphere was heated at $70{ }^{\circ} \mathrm{C}$ for $16 \mathrm{~h}$. The reaction progress was monitored by TLC ( $2 \%$ EtOAc in PET) and HPLC. The mixture was diluted with EtOAc $(50 \mathrm{~mL})$ and washed with brine $(30 \mathrm{~mL} \times 3)$. The organic layer was dried over $\mathrm{MgSO}_{4}$ and evaporated under reduced pressure. The resulting brown oil was purified by column chromatography (2\% EtOAc in PET) to afford a white solid (750 mg, $\left.3.36 \mathrm{mmol}, 92 \%) .{ }^{1} \mathrm{H} \mathrm{NMR} \mathrm{(400} \mathrm{MHz}, \mathrm{CDCl}_{3}\right)$ $\delta$ 7.61-7.57 (m, 2H, Ph), 7.53-7.48 (m, 3H, Ph), $7.47(\mathrm{~s}, 2 \mathrm{H}$, pyridinyl). HNMR in accordance with the literature.

2-(tert-Butylthio)-6-chloro-4-phenylpyridine (27). A suspension of 2,6-dichloro-4-phenylpyridine 26 ( $0.2 \mathrm{~g}, 0.89 \mathrm{mmol}, 1.0$ equiv), $\mathrm{Cs}_{2} \mathrm{CO}_{3}(0.58 \mathrm{~g}, 1.78 \mathrm{mmol}, 2.0$ equiv), and 2-methylpropane-2-thiol $\left(0.084 \mathrm{~g}, 0.93 \mathrm{mmol}, 1.04\right.$ equiv) in DMF was heated at $80{ }^{\circ} \mathrm{C}$ overnight. The reaction progress was monitored by TLC (10\% EtOAc in PET) and HPLC. The mixture was diluted with EtOAc $(50 \mathrm{~mL})$ and washed with brine $(30 \mathrm{~mL} \times 5)$. The organic phase was dried on $\mathrm{MgSO}_{4}$ and evaporated to afford a pale yellow oil $(249 \mathrm{mg}, 0.89$ mmol, quantitative yield). ${ }^{1} \mathrm{H} \mathrm{NMR}\left(400 \mathrm{MHz}, \mathrm{CDCl}_{3}\right) \delta 7.69-7.54$ $(\mathrm{m}, 2 \mathrm{H}, \mathrm{Ph}), 7.50-7.43(\mathrm{~m}, 3 \mathrm{H}, \mathrm{Ph}), 7.37(\mathrm{~d}, J=1.2 \mathrm{~Hz}, 1 \mathrm{H}$, pyridinyl), $7.26(\mathrm{~d}, J=1.2 \mathrm{~Hz}, 1 \mathrm{H}$, pyridinyl) 1.59 (s, 9H, $t$-butyl). MS (ESI): calcd for $\mathrm{C}_{15} \mathrm{H}_{16} \mathrm{ClNS}[\mathrm{M}+\mathrm{H}]^{+}$, 278.07; found, 277.90.

tert-Butyl-(6-(tert-butylthio)-4-phenylpyridin-2-yl)-carbamate (28). A suspension of 2-(tert-butylthio)-6-chloro-4-phenylpyridine 27 $\left(0.23 \mathrm{~g}, 0.83 \mathrm{mmol}, 1.0\right.$ equiv), $\mathrm{Cs}_{2} \mathrm{CO}_{3}(0.54 \mathrm{~g}, 1.66 \mathrm{mmol}, 2.0$ equiv), Xantphos (0,144 g, $0.25 \mathrm{mmol}, 0.3$ equiv), $\mathrm{Pd}(\mathrm{OAc})_{2}(0.028$ g, $0.124 \mathrm{mmol}, 0.15$ equiv), and $t$-butyl carbamate $(0.097 \mathrm{~g}, 0.83$ mmol, 1.0 equiv) in dry 1,4-dioxane $(2.8 \mathrm{~mL})$ under a $\mathrm{N}_{2}$ atmosphere was heated at $110^{\circ} \mathrm{C}$ overnight. The reaction progress was monitored by TLC ( $2 \%$ EtOAc in PET) and HPLC. The mixture was treated with warm acetone $(25 \mathrm{~mL})$ and filtered. The organic layer was evaporated and purified by column chromatography (20\% EtOAc in PET) to afford 28 as a yellow solid ( $80 \mathrm{mg}, 0.22 \mathrm{mmol}, 27 \%) .{ }^{1} \mathrm{H}$ NMR (400 MHz, DMSO) $\delta 9.96(\mathrm{~s}, 1 \mathrm{H}, \mathrm{NH}), 7.84(\mathrm{~d}, J=1.6 \mathrm{~Hz}$, $1 \mathrm{H}), 7.67(\mathrm{~d}, J=6.8 \mathrm{~Hz}, 2 \mathrm{H}, \mathrm{Ph}), 7.54-7.44(\mathrm{~m}, 3 \mathrm{H}, \mathrm{Ph}), 7.15(\mathrm{~d}, J$ $=1.6 \mathrm{~Hz}, 1 \mathrm{H}), 1.53(\mathrm{~s}, 9 \mathrm{H}), 1.50(\mathrm{~s}, 9 \mathrm{H})$. MS (ESI): calcd for $\mathrm{C}_{20} \mathrm{H}_{26} \mathrm{~N}_{2} \mathrm{O}_{2} \mathrm{~S}[\mathrm{M}+\mathrm{H}]^{+}$, 359.17; found, 358.9.

6-(tert-Butylthio)-4-phenylpyridin-2-amine (29). To a solution of tert-butyl (6-(tert-butylthio)-4-phenylpyridin-2-yl)-carbamate 28 $\left(0.25 \mathrm{~g}, 0.697 \mathrm{mmol}, 1.0\right.$ equiv) in $\mathrm{CH}_{2} \mathrm{Cl}_{2}(5 \mathrm{~mL})$ was added TFA (0.266 mL, $3.48 \mathrm{mmol}, 5.0$ equiv). The mixture was refluxed overnight. The reaction progress was monitored by TLC $(6 \% \mathrm{MeOH}$ in $\mathrm{CH}_{2} \mathrm{Cl}_{2}$ ) and HPLC. The mixture was diluted with EtOAc (50 $\mathrm{mL})$ and washed with $\mathrm{H}_{2} \mathrm{O}(25 \mathrm{~mL} \times 4)$. The organic phase was dried on $\mathrm{MgSO}_{4}$ and evaporated to afford a brown oil. The crude compound was purified by liquid chromatography (50\% EtOAc in PET) to give 29 as a pale yellow oil $(135 \mathrm{mg}, 0.523 \mathrm{mmol}, 75 \%) .{ }^{1} \mathrm{H}$ NMR (400 MHz, DMSO) $\delta 7.66(\mathrm{dd}, J=6.8,2.0 \mathrm{~Hz}, 2 \mathrm{H}, \mathrm{Ph}), 7.54-$ $7.47(\mathrm{~m}, 3 \mathrm{H}, \mathrm{Ph}), 6.96\left(\mathrm{~s} \mathrm{br}, 1 \mathrm{H}, 0.5 \mathrm{NH}_{2}\right), 6.76\left(\mathrm{~s} \mathrm{br}, 1 \mathrm{H}, 0.5 \mathrm{NH}_{2}\right)$, 1.46 (s, 9H, t-butyl). MS (ESI): calcd for $\mathrm{C}_{15} \mathrm{H}_{18} \mathrm{~N}_{2} \mathrm{~S}[\mathrm{M}+\mathrm{H}]^{+}$, 259.12; found, $259.0[\mathrm{M}+\mathrm{H}]^{+}$. 
6-Amino-4-phenylpyridine-2-thiol (30). A stirred solution of 6(tert-butylthio)-4-phenylpyridin-2-amine 29 (0.445 g, $1.722 \mathrm{mmol})$ in $37 \% \mathrm{HCl}(15 \mathrm{~mL})$ was heated at $100{ }^{\circ} \mathrm{C}$ for $10 \mathrm{~h}$. The reaction progress was monitored by HPLC. The mixture was carefully treated with $\mathrm{NaHCO}_{3}$ saturated solution to $\mathrm{pH}=7$ and extracted with EtOAc $(40 \mathrm{~mL} \times 5)$. The organic phase was dried over $\mathrm{MgSO}_{4}$ and evaporated to afford an orange solid $(135 \mathrm{mg}$, mixture of the desired compound and the corresponding dimer). The compound was used for the next reaction without further purification. ${ }^{1} \mathrm{H}$ NMR (400 $\mathrm{MHz}, \mathrm{DMSO}) \delta 12.25$ (s br, $1 \mathrm{H}, \mathrm{SH}), 7.59-7.55$ (m, 2H, Ph), 7.49$7.43(\mathrm{~m}, 3 \mathrm{H}, \mathrm{Ph}), 6.85$ (s br, 1H, $0.5 \mathrm{NH}_{2}$ ), $6.40\left(\mathrm{~s} \mathrm{br}, 1 \mathrm{H}, 0.5 \mathrm{NH}_{2}\right.$ ). MS (ESI): calcd for $\mathrm{C}_{11} \mathrm{H}_{10} \mathrm{~N}_{2} \mathrm{~S}[\mathrm{M}+\mathrm{H}]^{+}, 203.06$; found, 203.1.

6-(((1H-Imidazol-2-yl)methyl)thio)-4-phenylpyridin-2-amine (5). To a suspension of 6-amino-4-phenylpyridine-2-thiol 30 (0.145 g, $0.716 \mathrm{mmol}, 1.0$ equiv) and $\mathrm{NaHCO}_{3}(0.061 \mathrm{~g}, 0.57 \mathrm{mmol}, 0.8$ equiv) in dry DMF $(2 \mathrm{~mL})$ was added $7(0.225 \mathrm{~g}, 0.931 \mathrm{mmol}, 1.3$ equiv). The mixture was stirred at room temperature for $23 \mathrm{~h}$. The reaction progress was monitored by HPLC. DMF was evaporated under reduced pressure (water bath at $70{ }^{\circ} \mathrm{C}$ ). The resulting residue was treated with $\mathrm{H}_{2} \mathrm{O}(20 \mathrm{~mL})$ and extracted with EtOAc $(30 \mathrm{~mL} \times 4)$. The organic phase was dried over $\mathrm{MgSO}_{4}$ and evaporated to afford an orange oil. The compound was purified by liquid chromatography $\left(10 \% \mathrm{MeOH}\right.$ in $\left.\mathrm{CH}_{2} \mathrm{Cl}_{2}\right)$ to obtain pure 5 as a pale red solid $(67 \mathrm{mg}$; $0.24 \mathrm{mmol}$; yield, $33 \%)$. Mp $109^{\circ} \mathrm{C} .{ }^{1} \mathrm{H}$ NMR $(400 \mathrm{MHz}, \mathrm{MeOD}) \delta$ 7.55-7.50 (m, 2H, Ph), 7.46-7.32 (m, 3H, Ph), 6.94 (s, $2 \mathrm{H}$, pyridinyl), $6.70(\mathrm{~d}, J=1.2 \mathrm{~Hz}, 1 \mathrm{H}$, imidazolyl), $6.50(\mathrm{~d}, J=1.2 \mathrm{~Hz}$, $1 \mathrm{H}$, imidazolyl), 4.39 (s, $2 \mathrm{H}, \mathrm{CH}_{2}$ ). MS (ESI): calcd for $\mathrm{C}_{15} \mathrm{H}_{14} \mathrm{~N}_{4} \mathrm{~S}$ $[\mathrm{M}+\mathrm{H}]^{+}, 283.09$; found, 283.00. HPLC: 3.722 min; purity: $97 \%$.

2,6-Dihydroxy-4-phenylnicotinonitrile (32). ${ }^{30}$ A suspension of commercially available ethylbenzoyl acetate $31(3 \mathrm{~g}, 15.6 \mathrm{mmol}, 1.0$ equiv), 2-cyanoacetamide ( $1.31 \mathrm{~g}, 15.6 \mathrm{mmol}, 1.0$ equiv), and $\mathrm{KOH}$ $(0.96 \mathrm{~g}, 15.6 \mathrm{mmol}, 1.0$ equiv) in EtOH $(20 \mathrm{~mL})$ was refluxed for 24 h. The reaction progress was monitored by HPLC and TLC $(20 \%$ $\mathrm{MeOH}$ in $\left.\mathrm{CH}_{2} \mathrm{Cl}_{2}\right)$. After the completion of the reaction, the mixture was cooled down to $0{ }^{\circ} \mathrm{C}$. The suspended solid was collected by filtration and subsequently dissolved in warm water $(60 \mathrm{~mL})$. The alkaline solution was carefully treated with $37 \% \mathrm{HCl}$ solution to adjust the $\mathrm{pH}$ to 1 . The precipitate was collected by filtration and dried to give 32 in good yield (1.3 g, $5.3 \mathrm{mmol}, 34 \%) .{ }^{1} \mathrm{H}$ NMR (400 MHz, DMSO) $\delta 7.52(\mathrm{~s}, 5 \mathrm{H}, \mathrm{Ph}), 5.80$ (s, $1 \mathrm{H}$, pyridinyl). MS (ESI): calcd for $\mathrm{C}_{12} \mathrm{H}_{8} \mathrm{~N}_{2} \mathrm{O} 2[\mathrm{M}+\mathrm{H}]^{+}$, 213.06; found, 213.1. HNMR is consistent with the reported literature data.

2,6-Dichloro-4-phenylnicotinonitrile (33). A suspension of 2,6dihydroxy-4-phenylnicotinonitrile 32 (1.2 g, $5.657 \mathrm{mmol}, 1.0$ equiv) in $\mathrm{POCl}_{3}\left(5.3 \mathrm{~mL}, 56.6 \mathrm{mmol}, 10.0\right.$ equiv) was heated at $180^{\circ} \mathrm{C}$ in an autoclave for $16 \mathrm{~h}$. The reaction progress was monitored by HPLC. The mixture was cooled down to $0{ }^{\circ} \mathrm{C}$ and treated with crushed ice. The suspended solid was collected by filtration, rinsed with petroleum ether $(30 \mathrm{~mL})$, and dried under reduced pressure to afford 33 as a gray solid (0.990 g, $3.96 \mathrm{mmol}, 70 \%) .{ }^{1} \mathrm{H} \mathrm{NMR}\left(400 \mathrm{MHz}, \mathrm{CDCl}_{3}\right) \delta$ $7.63-7.60(\mathrm{~m}, 5 \mathrm{H}, \mathrm{Ph}), 7.45$ (s, $1 \mathrm{H}$, pyridinyl). HNMR is consistent with the reported literature data.

tert-Butyl-(6-chloro-5-cyano-4-phenylpyridin-2-yl)-carbamate (34). To a suspension of 2,6-dichloro-4-phenylnicotinonitrile $33(0.2$ g, $0.806 \mathrm{mmol}, 1.0$ equiv), $t$-butyl carbamate $(0.095 \mathrm{~g}, 0.806 \mathrm{mmol}$, 1.0 equiv), $\mathrm{Cs}_{2} \mathrm{CO}_{3}(0.54 \mathrm{~g}, 1.66 \mathrm{mmol}, 2.06$ equiv), and Xantphos $(0.139 \mathrm{~g}, 0.242 \mathrm{mmol}, 0.3$ equiv) in dry 1,4-dioxane $(2.7 \mathrm{~mL})$ under a $\mathrm{N}_{2}$ atmosphere was added $\mathrm{Pd}(\mathrm{OAc})_{2}(0.027 \mathrm{~g}, 0.121 \mathrm{mmol}, 0.15$ equiv). The mixture was heated at $40{ }^{\circ} \mathrm{C}$ for $23 \mathrm{~h}$. The reaction progress was monitored by TLC ( $2 \%$ EtOAc in PET) and HPLC. The mixture was then treated with warm acetone $(25 \mathrm{~mL})$ and filtered. The organic layer was evaporated to afford a pale brown solid ( $90 \mathrm{mg}, 0.26 \mathrm{mmol}, 33 \%$ ). The product was used for the next reaction without further purification. ${ }^{1} \mathrm{H}$ NMR $\left(300 \mathrm{MHz}, \mathrm{CDCl}_{3}\right) \delta 8.07$ (s, $1 \mathrm{H}$, pyridinyl), 7.64-7.58 (m, 2H, Ph), 7.55-7.47 (m, 4H, Ph + $\mathrm{NH}), 1.53\left(\mathrm{~s}, 9 \mathrm{H}, t\right.$-butyl). MS (ESI): calcd for $\mathrm{C}_{17} \mathrm{H}_{16} \mathrm{ClN}_{3} \mathrm{O}_{2}[\mathrm{M}+$ $\mathrm{H}]^{+}$, 330.09; found, 329.92.

tert-Butyl (6-(tert-butylthio)-5-cyano-4-phenylpyridin-2-yl)-carbamate (35). A suspension of tert-butyl (6-chloro-5-cyano-4phenylpyridin-2-yl)-carbamate 34 (0.09 g, $0.273 \mathrm{mmol}, 1.0$ equiv), 2-methyl-propanethiol (0.03 mL, $0.273 \mathrm{mmol}, 1.0$ equiv), and $\mathrm{Cs}_{2} \mathrm{CO}_{3}(0.178 \mathrm{~g}, 0.56 \mathrm{mmol}, 2$ equiv) in DMF $(2 \mathrm{~mL})$ was heated at $90{ }^{\circ} \mathrm{C}$ for $20 \mathrm{~h}$. The reaction progress was monitored by HPLC. The mixture was cooled down to room temperature, diluted with EtOAc $(50 \mathrm{~mL})$, and washed with brine $(25 \mathrm{~mL} \times 5)$. The organic layer was dried on $\mathrm{MgSO}_{4}$ and evaporated to afford an orange oil (93 $\mathrm{mg}, 0.211 \mathrm{mmol}, 89 \%)$. The compound was used for the next reaction without further purification. ${ }^{1} \mathrm{H}$ NMR $\left(400 \mathrm{MHz}, \mathrm{CDCl}_{3}\right) \delta 7.81(\mathrm{~s}$, $1 \mathrm{H}$, pyridinyl), 7.59-7.55 (m, 2H, Ph), 7.48-7.44 (m, 3H, Ph), 7.32 $(\mathrm{s}$ br, $1 \mathrm{H}, \mathrm{NH}), 1.65$ (s, $9 \mathrm{H}, t$-butyl), $1.54(\mathrm{~s}, 9 \mathrm{H}, t$-butyl). MS (ESI): calcd for $\mathrm{C}_{21} \mathrm{H}_{25} \mathrm{~N}_{3} \mathrm{O}_{2} \mathrm{~S}[\mathrm{M}+\mathrm{H}]^{+}$, 384.17; found, 284.00.

6-Amino-2-sulfanyl-4-phenylnicotinonitrile (36). A suspension of $35(0.7 \mathrm{~g}, 1.825 \mathrm{mmol})$ in $37 \% \mathrm{HCl}(7 \mathrm{~mL})$ was heated at $100{ }^{\circ} \mathrm{C}$ for $2 \mathrm{~h}$. The reaction progress was monitored by HPLC. The mixture was cooled down to room temperature and diluted with $\mathrm{NaHCO}_{3}$ saturated solution $(7 \mathrm{~mL})$. The resulting suspension was treated carefully with solid $\mathrm{NaHCO}_{3}$ to $\mathrm{pH} 7$ and extracted with EtOAc (30 $\mathrm{mL} \times 5$ ). The organic layer was dried over $\mathrm{MgSO}_{4}$ and evaporated to afford an orange solid, which was purified by column chromatography (40\% EtOAc in PET and $10 \% \mathrm{MeOH}$ in $\mathrm{CH}_{2} \mathrm{Cl}_{2}$ ). Intermediate 36 was obtained as a pale yellow solid $(156 \mathrm{mg}, 0.675 \mathrm{mmol}, 37 \%) .{ }^{1} \mathrm{H}$ NMR (400 MHz, MeOD) $\delta$ 7.56-7.51 (m, 2H, Ph), 7.51-7.47 (m, $3 \mathrm{H}, \mathrm{Ph}$ ), 6.05 (s, $1 \mathrm{H}$, pyridinyl). MS (ESI): calcd for $\mathrm{C}_{12} \mathrm{H}_{9} \mathrm{~N}_{3} \mathrm{~S}[\mathrm{M}+$ $\mathrm{H}]^{+}, 228.05$; found, 228.08 .

2-(((1H-Imidazol-2-yl)methyl)thio)-6-amino-4-phenylnicotinonitrile (6). A suspension of 36 (0.096 g, $0.422 \mathrm{mmol}, 1.0$ equiv), $\mathrm{NaHCO}_{3}(0.020 \mathrm{~g}, 0.422 \mathrm{mmol}, 1.0$ equiv), and 7 in dry DMF (2.5 $\mathrm{mL}$ ) was stirred at room temperature for $4 \mathrm{~h}$. The reaction progress was monitored by TLC $\left(10 \% \mathrm{MeOH}\right.$ in $\left.\mathrm{CH}_{2} \mathrm{Cl}_{2}\right)$. DMF was evaporated under reduced pressure (water bath at $70{ }^{\circ} \mathrm{C}$ ). The resulting residue was treated with water $(10 \mathrm{~mL})$ and extracted with EtOAc $(30 \mathrm{~mL} \times 5)$. The organic layer was dried over $\mathrm{MgSO}_{4}$ and evaporated to afford a pale brown oil. The final compound 6 was obtained after purification by column chromatography (PET/EtOAc/ $\mathrm{MeOH}, 1: 7.8: 1.2)$ and recrystallized using diethyl ether and $\mathrm{MeOH}$ to yield 6 as a pale yellow solid (10 mg; $0.032 \mathrm{mmol}$; yield, $8 \%)$. Mp $222^{\circ} \mathrm{C} .{ }^{1} \mathrm{H}$ NMR (400 MHz, MeOD) $\delta 7.53-7.45$ (m, 5H, Ph), 6.97 (s, $2 \mathrm{H}$, imidazolyl), 6.28 (s, $1 \mathrm{H}$, pyridinyl), $4.53\left(\mathrm{~s}, 2 \mathrm{H}, \mathrm{CH}_{2}\right) . \mathrm{MS}$ (ESI): calcd for $\mathrm{C}_{16} \mathrm{H}_{13} \mathrm{~N}_{5} \mathrm{~S}[\mathrm{M}+\mathrm{H}]^{+}, 308.09$; found, 308.00. HPLC: $7.490 \mathrm{~min}$; purity: $99 \%$.

Pharmacology. Cell Lines and Chemicals. Chinese hamster ovary $(\mathrm{CHO})$ cells stably expressing the human adenosine $A_{1}$ receptor $\left(\mathrm{CHOhA}_{1} \mathrm{R}\right)$ were kindly provided by Prof. S. J. Hill (University of Nottingham, U.K.), human embryonic kidney 293 cells stably expressing the human adenosine $\mathrm{A}_{2 \mathrm{~A}}$ receptor $\left(\mathrm{HEK}_{293} \mathrm{~h} \mathrm{~A}_{2 \mathrm{~A}} \mathrm{R}\right)$ were kindly provided by Dr. J. Wang (Biogen/IDEC, Cambridge, $\mathrm{MA}$ ), CHO-spap cells stably expressing the wild-type (WT) $\mathrm{hA}_{2 \mathrm{~B}}$ receptor $\left(\mathrm{CHO}\right.$-spap-hA $\left.\mathrm{A}_{2 \mathrm{~B}} \mathrm{R}\right)$ were kindly provided by $\mathrm{S}$. J. Dowell (GlaxoSmithKline, U.K.), and CHO cells stably expressing the human adenosine $\mathrm{A}_{3}$ receptor $\left(\mathrm{CHOhA}_{3} \mathrm{R}\right)$ were a gift from Dr. K.-N. Klotz (University of Würzburg, Germany). $\left[{ }^{3} \mathrm{H}\right] 1,3$-Dipropyl-8-cyclopentylxanthine $\left(\left[{ }^{3} \mathrm{H}\right] D P C P X ;\right.$ specific activity, $\left.120 \mathrm{Ci} / \mathrm{mmol}\right)$ was purchased from ARC, Inc. (St. Louis, USA), $\left[{ }^{3} \mathrm{H}\right] 4-(2-[7$-amino-2(furan-2-yl)-[1,2,4]triazolo[1,5-a][1,3,5]triazin-5-ylamino)ethyl) phenol $\left(\left[{ }^{3} \mathrm{H}\right]-Z M 241385\right.$; specific activity, $\left.50 \mathrm{Ci} / \mathrm{mmol}\right)$ was purchased from ARC, Inc. (St. Louis, USA), $\left[{ }^{3} \mathrm{H}\right] 8$-(4-(4-(4-chlorophenyl)piperazide-1-sulfonyl)phenyl)-1-propylxanthine ([$\left.{ }^{3} \mathrm{H}\right] \mathrm{PSB}-603$; specific activity, $79 \mathrm{Ci} / \mathrm{mmol}$ ) was purchased from Quotient Bioresearch (Waltham, MA), and $\left[{ }^{3} \mathrm{H}\right] 8$-ethyl-4-methyl-2-phenyl-(8R)-4,5,7,8tetrahydro- $1 \mathrm{H}$-imidazo[2,1-i]-purin-5-one ([ $\left.{ }^{3} \mathrm{H}\right] \mathrm{PSB}-11$; specific activity, $56 \mathrm{Ci} / \mathrm{mmol})$ was obtained with the kind help of Prof. C. E. Müller (University of Bonn, Germany). 5'-N-Ethylcarboxamidoadenosine (NECA), $\mathrm{N}^{6}$-cyclopentyladenosine (CPA), and adenosine deaminase (ADA) were purchased from Sigma-Aldrich (Steinheim, Germany). Unlabeled 4-(2-[7-amino-2-(furan-2-yl)-[1,2,4]triazolo$[1,5-a][1,3,5]$ triazin-5-ylamino)ethyl) phenol $(\mathrm{ZM} 241385)$ was a kind gift from Dr. S. M. Poucher (Astra Zeneca, Manchester, U.K.). 3-[4-[2-[[6-Amino-9-[(2R,3R,4S,5S)-5-(ethylcarbamoyl)-3,4-dihydroxy-oxolan-2-yl]purin-2-yl]amino] ethyl]phenyl] propanoic acid (CGS21680) was purchased from Ascent Scientific (Bristol, U.K.). 
Bicinchoninic acid (BCA) protein assay reagents were obtained from Pierce Chemical Company (Rockford, IL, USA). All other chemicals were of analytical grade and were obtained from standard commercial sources.

Cell Culture and Membrane Preparation. $\mathrm{CHOhA}_{1} \mathrm{R}$ and $\mathrm{CHOhA}_{3} \mathrm{R}$ cells were grown in Dulbecco's modified Eagle's medium (DMEM) and Ham's F12 medium (1:1) supplemented with 10\% (v/ v) newborn calf serum, $50 \mu \mathrm{g} \cdot \mathrm{mL}^{-1}$ streptomycin, $50 \mathrm{IU} \cdot \mathrm{mL}^{-1}$ penicillin, and $200 \mu \mathrm{g} \cdot \mathrm{mL}^{-1} \mathrm{G} 418$ at $37{ }^{\circ} \mathrm{C}$ and $5 \% \mathrm{CO}_{2} . \mathrm{CHOhA}_{1} \mathrm{R}$ cells were subcultured twice a week at a ratio of $1: 20$ on $10 \mathrm{~cm} \varnothing$ plates and $15 \mathrm{~cm} \varnothing$ plates. $\mathrm{CHOhA}_{3}$ cells were subcultured twice a week at a ratio of $1: 8$ on $10 \mathrm{~cm} \varnothing$ plates and $15 \mathrm{~cm} \varnothing$ plates. $\mathrm{HEK}_{293} \mathrm{hA}_{2 \mathrm{~A}} \mathrm{R}$ cells were grown in a culture medium consisting of Dulbecco's modified Eagle's medium (DMEM) supplemented with $10 \%$ newborn calf serum, $50 \mu \mathrm{g} \cdot \mathrm{mL}^{-1}$ streptomycin, $50 \mathrm{IU} \cdot \mathrm{mL}^{-1}$ penicillin, and $500 \mu \mathrm{g} \cdot \mathrm{mL}^{-1} \mathrm{G} 418$ at $37^{\circ} \mathrm{C}$ and $7 \% \mathrm{CO}_{2}$. Cells were subcultured twice a week at a ratio of $1: 8$ on $10 \mathrm{~cm} \varnothing$ plates and 15 $\mathrm{cm} \varnothing$ plates. CHO-spap- $h \mathrm{~A}_{2 \mathrm{~B}} \mathrm{R}$ cells were grown in Dulbecco's modified Eagle's medium (DMEM) and Ham's F12 medium (1:1) supplemented with $10 \%(\mathrm{v} / \mathrm{v})$ newborn calf serum, $100 \mu \mathrm{g} \cdot \mathrm{mL}^{-1}$ streptomycin, $100 \mathrm{IU} \cdot \mathrm{mL}^{-1}$ penicillin, $1 \mathrm{mg} \cdot \mathrm{mL}^{-1} \mathrm{G} 418$, and $0.4 \mathrm{mg}$. $\mathrm{mL}^{-1}$ hygromycin at $37{ }^{\circ} \mathrm{C}$ and $5 \% \mathrm{CO}_{2}$. Cells were subcultured at a ratio of 1:20 twice weekly.

All cells were grown to $80-90 \%$ confluency and detached from plates by scraping them into $5 \mathrm{~mL}$ of PBS. Detached cells were collected and centrifuged at $200 \mathrm{~g}$ for $5 \mathrm{~min}$. Pellets derived from 100 $15 \mathrm{~cm} \emptyset$ plates were pooled and resuspended in $70 \mathrm{~mL}$ of ice-cold 50 $\mathrm{mM}$ Tris- $\mathrm{HCl}$ buffer (pH 7.4). A Heidolph Diax 900 homogenizer was used to homogenize the cell suspension. Membranes and the cytosolic fraction were separated by centrifugation at 100,000 $\mathrm{g}$ in a Beckman Optima LE-80K ultracentrifuge (Beckman Coulter, Fullerton, CA) at $4{ }^{\circ} \mathrm{C}$ for $20 \mathrm{~min}$. The pellet was resuspended in $35 \mathrm{~mL}$ of Tris- $\mathrm{HCl}$ buffer, and the homogenization and centrifugation steps were repeated. Tris- $\mathrm{HCl}$ buffer $(25 \mathrm{~mL})$ was used to resuspend the pellet, and ADA was added $(0.8 \mathrm{U} / \mathrm{mL})$ to break down endogenous adenosine. Membranes were stored in 250 and $500 \mu \mathrm{L}$ aliquots at -80 ${ }^{\circ} \mathrm{C}$. Total protein concentrations were measured using the BCA method. ${ }^{50}$

Radioligand Binding Studies. Membrane aliquots containing $5 \mu \mathrm{g}$ $\left(\mathrm{CHOhA}_{1} \mathrm{R}\right)$ or $30 \mu \mathrm{g}\left(\mathrm{HEK}_{293} \mathrm{hA} \mathrm{A}_{2 \mathrm{~A}} \mathrm{R}\right)$ of total protein were incubated in a total volume of $100 \mu \mathrm{L}$ assay buffer $(50 \mathrm{mM}$ Tris$\mathrm{HCl}, \mathrm{pH} 7.4)$ at $25^{\circ} \mathrm{C}$ for $1 \mathrm{~h}$. Membrane aliquots containing $30 \mu \mathrm{g}$ $\left(\mathrm{CHO}\right.$-spap- $\left.\mathrm{h} \mathrm{A}_{2 \mathrm{~B}} \mathrm{R}\right)$ of total protein were incubated in a total volume of $100 \mu \mathrm{L}$ assay buffer (0.1\% CHAPS in $50 \mathrm{mM}$ Tris-HCl, pH 7.4) at $25{ }^{\circ} \mathrm{C}$ for $2 \mathrm{~h}$, or those containing $15 \mu \mathrm{g}\left(\mathrm{CHOhA}_{3} \mathrm{R}\right)$ of total protein were incubated in a total volume of $100 \mu \mathrm{L}$ assay buffer $(50 \mathrm{mM}$ Tris- $\mathrm{HCl}$, pH 8.0, supplemented with $10 \mathrm{mM} \mathrm{MgCl}, 1 \mathrm{mM}$ EDTA, and $0.01 \%(\mathrm{w} / \mathrm{v}) \mathrm{CHAPS})$ at $25^{\circ} \mathrm{C}$ for $2 \mathrm{~h}$. Radioligand displacement experiments were performed using six concentrations of the competing ligand in the presence of $1.6 \mathrm{nM}\left[{ }^{3} \mathrm{H}\right] \mathrm{DPCPX}$ for $\mathrm{CHOhA}_{1} \mathrm{R}$, $5.5 \mathrm{nM}\left[{ }^{3} \mathrm{H}\right] \mathrm{ZM} 241385$ for $\mathrm{HEK}_{293} \mathrm{hA}_{2 \mathrm{~A}} \mathrm{R}, \quad 1.5 \mathrm{nM}$ $\left[{ }^{3} \mathrm{H}\right]$ PSB-603 for CHO-spap-hA ${ }_{2 B} \mathrm{R}$, and $10 \mathrm{nM}\left[{ }^{3} \mathrm{H}\right]$ PSB-11 for $\mathrm{CHOhA}_{3} \mathrm{R}$. At these concentrations, the total radioligand binding did not exceed $10 \%$ of that added to prevent ligand depletion. Nonspecific binding was determined in the presence of $100 \mu \mathrm{M}$ CPA for $\mathrm{CHOhA}_{1} \mathrm{R}, 100 \mu \mathrm{M}$ NECA for $\mathrm{HEK}_{293} \mathrm{hA}_{2 \mathrm{~A}} \mathrm{R}$ and $\mathrm{CHOhA}_{3} \mathrm{R}$, and 10 $\mu \mathrm{M}$ ZM241385 for CHO-spap- $h \mathrm{~A}_{2 \mathrm{~B}} \mathrm{R}$. Incubations were terminated by rapid vacuum filtration to separate the bound and free radioligands through prewetted 96-well GF/B filter plates using a PerkinElmer Filtermate-harvester (PerkinElmer, Groningen, The Netherlands). Filters were subsequently washed 12 times with ice-cold wash buffer: $50 \mathrm{mM}$ Tris- $\mathrm{HCl}\left(\mathrm{pH}\right.$ 7.4) for $\mathrm{CHOhA}_{1} \mathrm{R}$ and $\mathrm{HEK}_{293} \mathrm{hA}_{2 \mathrm{~A}} \mathrm{R}, 0.1 \%$ BSA in $50 \mathrm{mM}$ Tris- $\mathrm{HCl}\left(\mathrm{pH}\right.$ 7.4) for CHO-spap-hA $\mathrm{A}_{2 \mathrm{~B}} \mathrm{R}$, and 50 $\mathrm{mM}$ Tris- $\mathrm{HCl}$ supplemented with $10 \mathrm{mM} \mathrm{MgCl}$ and $1 \mathrm{mM}$ EDTA $\left(\mathrm{pH}\right.$ 8.0) for $\mathrm{CHOhA}_{3} \mathrm{R}$. The plates were dried at $55^{\circ} \mathrm{C}$ after which MicroScint-20 cocktail was added (PerkinElmer, Groningen, The Netherlands). After $3 \mathrm{~h}$, the filter-bound radioactivity was determined by scintillation spectrometry using a 2450 MicroBeta Microplate Counter (PerkinElmer, Groningen, The Netherlands).
Label-Free Impedance-Based Assay. Label-free whole-cell assays were performed on the xCELLigence real-time cell analyzer (RTCA) system. ${ }^{51,52}$ In this system, the cells are adhered to arrayed gold electrodes embedded at the bottom of microelectronic E-plate 96 (Bioké, Leiden, NL), which is compatible with the xCELLigence RTCA system (ACEA Bioscience, San Diego, CA, USA). Upon activation of GPCR-mediated signaling, the cell morphology changes and therefore affects the local ionic environment at the cell-electrode interface. This leads to an increased electronic readout of cell-sensor impedance $(Z)$, which is displayed in real time as the cell index $(\mathrm{CI})$. Specifically, the CI value at each time point is defined as $\left(Z_{\mathrm{i}}-Z_{0}\right) \Omega$ / $15 \Omega$, where $Z_{\mathrm{i}}$ is the impedance at each individual time point, and $Z_{0}$ is the impedance derived from the electrode/solution interface in the absence of cells prior to the start of the experiment. HEK293hA ${ }_{2 \mathrm{~A}} \mathrm{R}$ cells were cultured as a monolayer on $10 \mathrm{~cm} \varnothing$ culture plates to $80-$ $90 \%$ confluency and subsequently harvested and centrifuged two times at $1000 \mathrm{rpm}$ for $5 \mathrm{~min}$. Initially, $45 \mu \mathrm{L}$ of culture media was added to wells in E-plates 96 to obtain background readings $\left(Z_{0}\right)$ followed by the addition of $50 \mu \mathrm{L}$ of cell suspension containing 20,000 cells/well. The E-plate containing the cells was left at room temperature for $30 \mathrm{~min}$ before being placed on the recording device station in the incubator at $37{ }^{\circ} \mathrm{C}$ in $7 \% \mathrm{CO}_{2}$. Afterward, cell attachment, spreading, and proliferation were continuously monitored every $15 \mathrm{~min}$. The cells were cultured until the end of log phase $(\sim 18-20 \mathrm{~h})$ to obtain an optimal assay window. Prior to agonist application (either the reference compound CGS21680, 8, or newly synthesized compounds), the interval between two measurements was adjusted to $15 \mathrm{~s}$. Subsequently, $5 \mu \mathrm{L}$ of compound solution (final concentration of $0.1 \%$ DMSO) or vehicle control (0.1\% DMSO) was added to each well, after which the CI was recorded for $60 \mathrm{~min}$.

Molecular Modeling. All preparations and simulations were performed using Schrödinger Suite. ${ }^{53}$ The crystal structure of $\mathrm{hA}_{2 \mathrm{~A}} \mathrm{AR}$ in complex with compound $\mathbf{8}$ was obtained in-house (vide supra) and used for the in silico experiment. All thermostabilizing mutations were reverted to wild-type $h A_{2 A} A R$, the bRIL fusion protein was removed from the crystal structure, and the third intracellular loop (ICL3) was filled in using Prime. ${ }^{3,33,54}$ Missing water molecules in the binding pocket of the crystal structure were added from $4 \mathrm{EIY}^{3}$ The protein was prepared by the "Protein Preparation Wizard" at default settings. The compounds ( 1 and $\mathbf{3}$ ) were built and prepared using LigPrep. ${ }^{55}$ Induced-fit docking ${ }^{34}$ was performed flexibly with the crystal ligand 8 as the center of workspace in the standard protocol and OPLS3 as the force field. Figures were rendered using PyMol. ${ }^{56}$

Data Analysis. All experimental data were analyzed using the nonlinear regression curve fitting program GraphPad Prism 7.0 (GraphPad Software Inc., San Diego, CA). IC I0 $_{5}$ values obtained from competition displacement binding data were converted into $K_{\mathrm{i}}$ values using the Cheng-Prusoff equation. ${ }^{57}$ The $K_{\mathrm{D}}$ value of $\left[{ }^{3} \mathrm{H}\right] \mathrm{DPCPX}$ $(1.6 \mathrm{nM})$ at $\mathrm{CHOhA}_{1} \mathrm{R}$ membranes was taken from Kourounakis et al. ${ }^{58}$ The $K_{\mathrm{D}}$ value $(1.0 \mathrm{nM})$ of $\left[{ }^{3} \mathrm{H}\right] \mathrm{ZM} 241385$ at $\mathrm{hA} \mathrm{A}_{2 \mathrm{~A}} \mathrm{R}$ membranes, the $K_{D}$ value $(1.71 \mathrm{nM})$ of $\left[{ }^{3} \mathrm{H}\right] \mathrm{PSB}-603$ at $\mathrm{CHO}$-spap-h $\mathrm{A}_{2 \mathrm{~B}} \mathrm{R}$ membranes, and the $K_{\mathrm{D}}$ value $(17.3 \mathrm{nM})$ of $\left[{ }^{3} \mathrm{H}\right] \mathrm{PSB}-11$ at $\mathrm{CHOhA}_{3} \mathrm{R}$ membranes were taken from in-house determinations. Efficacy data from xCELLigence were obtained using RTCA software 1.2 (Roche, Germany) by normalizing CI traces to define peak responses within $60 \mathrm{~min}$ after compound addition. Peak values were used further for the determination of concentration-effect curves, yielding $\mathrm{EC}_{50}$ (concentration causing a half-maximum effect) and $E_{\max }$ (maximum effect relative to CGS21680) values.

\section{ASSOCIATED CONTENT}

\section{SI Supporting Information}

The Supporting Information is available free of charge at https://pubs.acs.org/doi/10.1021/acs.jmedchem.0c01856.

Additional figures of crystal structure and computational models (Figures S1-S3 and S5), graph of displacement curves (Figure S4), linear correlation plot (Figure S6), 
and HNMR and LCMS analyses of compounds 1-6 (PDF)

Molecular formula strings (CSV)

\section{AUTHOR INFORMATION}

\section{Corresponding Author}

Adriaan P. IJzerman - Division of Drug Discovery and Safety, Leiden Academic Centre for Drug Research, Leiden

University, 2333 CC Leiden, The Netherlands; 10 orcid.org/ 0000-0002-1182-2259; Phone: +31-71-5274651;

Email: ijzerman@lacdr.leidenuniv.nl

\section{Authors}

Tasia Amelia - Division of Drug Discovery and Safety, Leiden Academic Centre for Drug Research, Leiden University, 2333 CC Leiden, The Netherlands; School of Pharmacy, Bandung Institute of Technology, 40132 Bandung, Indonesia; (1) orcid.org/0000-0002-7414-9428

Jacobus P. D. van Veldhoven - Division of Drug Discovery and Safety, Leiden Academic Centre for Drug Research, Leiden University, 2333 CC Leiden, The Netherlands

Matteo Falsini - Division of Drug Discovery and Safety, Leiden Academic Centre for Drug Research, Leiden University, 2333 CC Leiden, The Netherlands

Rongfang Liu - Division of Drug Discovery and Safety, Leiden Academic Centre for Drug Research, Leiden University, 2333 CC Leiden, The Netherlands

Laura H. Heitman - Division of Drug Discovery and Safety, Leiden Academic Centre for Drug Research, Leiden University, 2333 CC Leiden, The Netherlands; (1) orcid.org/ 0000-0003-3662-8177

Gerard J. P. van Westen - Division of Drug Discovery and Safety, Leiden Academic Centre for Drug Research, Leiden University, 2333 CC Leiden, The Netherlands; (1) orcid.org/ 0000-0003-0717-1817

Elena Segala - Sosei Heptares, Cambridge CB21 6DG, United Kingdom

Grégory Verdon - Sosei Heptares, Cambridge CB21 6DG, United Kingdom

Robert K. Y. Cheng - Sosei Heptares, Cambridge CB21 6DG, United Kingdom

Robert M. Cooke - Sosei Heptares, Cambridge CB21 6DG, United Kingdom

Daan van der Es - Division of Drug Discovery and Safety, Leiden Academic Centre for Drug Research, Leiden University, 2333 CC Leiden, The Netherlands

Complete contact information is available at:

https://pubs.acs.org/10.1021/acs.jmedchem.0c01856

\section{Author Contributions}

T.A., L.H.H., G.J.P.v.W., D.v.d.E., R.M.C., and A.P.IJ. were involved in the study design. E.S., G.V., and R.K.Y.C. carried out the crystal structure determination. T.A., J.P.D.v.V., M.F., and D.v.d.E. conducted synthetic chemistry experiments. R.L., L.H.H., and A.P.IJ. performed pharmacology experiments. T.A. and G.J.P.v.W. carried out the computational study. T.A., J.P.D.v.V., L.H.H., G.J.P.v.W., E.S., G.V., R.M.C., D.v.d.E., and A.P.IJ. wrote the manuscript.

\section{Notes}

The authors declare no competing financial interest. The $8-\mathrm{hA}_{2 \mathrm{~A}} \mathrm{AR}$ complex structure coordinates and structure factors are available via the Protein Data Bank, accession code
(PDB ID) 7ARO. Receptor models with compounds 1 and 3 are available as well. The authors will release the atomic coordinates and experimental data upon article publication.

\section{ACKNOWLEDGMENTS}

T.A. acknowledges financial support by the Indonesia Endowment Fund for Education (LPDP). Eelke B. Lenselink is acknowledged for his help with the computational aspects of the study.

\section{ABBREVIATIONS USED}

bRIL, thermostabilized apocytochrome b562RIL; GPCR, G protein-coupled receptor; hAR, human adenosine receptor; mCPBA, meta-chloroperoxybenzoic acid; RTCA, real-time cell analysis; StaR, (thermo)stabilized receptor; TFA, trifluoroacetic acid

\section{REFERENCES}

(1) Fredholm, B. B.; IJzerman, A. P.; Jacobson, K. A.; Linden, J.; Müller, C. E. International Union of Basic and Clinical Pharmacology. LXXXI. Nomenclature and classification of adenosine receptors-an update. Pharmacol. Rev. 2011, 63, 1-34.

(2) Jaakola, V.-P.; Griffith, M. T.; Hanson, M. A.; Cherezov, V.; Chien, E. Y. T.; Lane, J. R.; IJzerman, A. P.; Stevens, R. C. The 2.6 angstrom crystal structure of a human $\mathrm{A}_{2 \mathrm{~A}}$ adenosine receptor bound to an antagonist. Science 2008, 322, 1211-1217.

(3) Liu, W.; Chun, E.; Thompson, A. A.; Chubukov, P.; Xu, F.; Katritch, V.; Han, G. W.; Roth, C. B.; Heitman, L. H.; IJzerman, A. P.; Cherezov, V.; Stevens, R. C. Structural basis for allosteric regulation of GPCRs by sodium ions. Science 2012, 337, 232-236.

(4) Jazayeri, A.; Andrews, S. P.; Marshall, F. H. Structurally enabled discovery of adenosine $\mathrm{A}_{2 \mathrm{~A}}$ receptor antagonists. Chem. Rev. 2017, $117,21-37$.

(5) Fredholm, B. B.; IJzerman, A. P.; Jacobson, K. A.; Klotz, K.-N.; Linden, J. International Union of Pharmacology. XXV. Nomenclature and classification of adenosine receptors. Pharmacol. Rev. 2001, 53, $527-552$.

(6) Rosentreter, U.; Henning, R.; Bauser, M.; Kraemer, T.; Vaupel, A.; Hübsch, W.; Dembowsky, K.; Salcher-Schräufstaetter, O.; Stasch, J.-P.; Krahn, T.; Perzborn, E. Substituted 2-thio-3,5-dicyano-4-aryl-6aminopyridines and the use thereof as adenosine receptor ligands. World patent WO2001025210, April 12, 2001.

(7) Rosentreter, U.; Kraemer, T.; Shimada, M.; Huebsch, W.; Diedrichs, N.; Krahn, T.; K, H.; Stasch, J. Preparation of 2heteroarylmethylthio-3,5-dicyano-4-phenyl-6-aminopyridines as adenosine receptor selective ligands. World patent WO03008384, January 30, 2003.

(8) Shah, S. J.; Voors, A. A.; McMurray, J. J. V.; Kitzman, D. W.; Viethen, T.; Bomfim Wirtz, A.; Huang, E.; Pap, A. F.; Solomon, S. D. Effect of neladenoson bialanate on exercise capacity among patients with heart failure with preserved ejection fraction: a randomized clinical trial. JAMA 2019, 321, 2101-2112.

(9) Betti, M.; Catarzi, D.; Varano, F.; Falsini, M.; Varani, K.; Vincenzi, F.; Dal Ben, D.; Lambertucci, C.; Colotta, V. The aminopyridine-3,5-dicarbonitrile core for the design of new nonnucleoside-like agonists of the human adenosine $\mathrm{A}_{2 \mathrm{~B}}$ receptor. Eur. J. Med. Chem. 2018, 150, 127-139.

(10) Eckle, T.; Krahn, T.; Grenz, A.; Köhler, D.; Mittelbronn, M.; Ledent, C.; Jacobson, M. A.; Osswald, H.; Thompson, L. F.; Unertl, K.; Eltzschig, H. K. Cardioprotection by ecto-5' -nucleotidase (CD73) and $\mathrm{A}_{2 \mathrm{~B}}$ adenosine receptors. Circulation 2007, 115, 1581-1590.

(11) Beukers, M. W.; Chang, L. C. W.; von Frijtag Drabbe Künzel, J. K.; Mulder-Krieger, T.; Spanjersberg, R. F.; Brussee, J.; IJzerman, A. $\mathrm{P}$. New, non-adenosine, high-potency agonists for the human adenosine $A_{2 B}$ receptor with an improved selectivity profile compared to the reference agonist $\mathrm{N}$-ethylcarboxamidoadenosine. J. Med. Chem. 2004, 47, 3707-3709. 
(12) Guo, D.; Mulder-Krieger, T.; IJzerman, A. P.; Heitman, L. H. Functional efficacy of adenosine $A_{2 A}$ receptor agonists is positively correlated to their receptor residence time. Br. J. Pharmacol. 2012, $166,1846-1859$.

(13) Segala, E.; Guo, D.; Cheng, R. K. Y.; Bortolato, A.; Deflorian, F.; Doré, A. S.; Errey, J. C.; Heitman, L. H.; IJzerman, A. P.; Marshall, F. H.; Cooke, R. M. Controlling the dissociation of ligands from the adenosine $\mathrm{A}_{2 \mathrm{~A}}$ receptor through modulation of salt bridge strength. J. Med. Chem. 2016, 59, 6470-6479.

(14) Rucktooa, P.; Cheng, R. K. Y.; Segala, E.; Geng, T.; Errey, J. C.; Brown, G. A.; Cooke, R. M.; Marshall, F. H.; Doré, A. S. Towards high throughput GPCR crystallography: In meso soaking of adenosine $\mathrm{A}_{2 \mathrm{~A}}$ receptor crystals. Sci. Rep. 2018, 8, 41.

(15) Ballesteros, J. A.; Weinstein, H. [19] Integrated methods for the construction of three-dimensional models and computational probing of structure-function relations in $\mathrm{G}$ protein-coupled receptors. Methods Neurosci 1995, 25, 366-428.

(16) Lane, J. R.; Klein Herenbrink, C.; van Westen, G. J. P.; Spoorendonk, J. A.; Hoffmann, C.; IJzerman, A. P. A novel nonribose agonist, LUF5834, engages residues that are distinct from those of adenosine-like ligands to activate the adenosine $\mathrm{A}_{2 \mathrm{~A}}$ receptor. $\mathrm{Mol}$. Pharmacol. 2012, 81, 475-487.

(17) Gao, Z.-G.; Jiang, Q.; Jacobson, K. A.; IJzerman, A. P. Sitedirected mutagenesis studies of human $\mathrm{A}_{2 \mathrm{~A}}$ adenosine receptors: involvement of $\mathrm{Glu}^{13}$ and $\mathrm{His}^{278}$ in ligand binding and sodium modulation. Biochem. Pharmacol. 2000, 60, 661-668.

(18) Lebon, G.; Warne, T.; Edwards, P. C.; Bennett, K.; Langmead, C. J.; Leslie, A. G. W.; Tate, C. G. Agonist-bound adenosine $A_{2 A}$ receptor structures reveal common features of GPCR activation. Nature 2011, 474, 521-525.

(19) Bertheleme, N.; Singh, S.; Dowell, S. J.; Hubbard, J.; Byrne, B. Loss of constitutive activity is correlated with increased thermostability of the human adenosine $\mathrm{A}_{2 \mathrm{~A}}$ receptor. $\mathrm{Br}$. J. Pharmacol. 2013, $169,988-998$.

(20) Louvel, J.; Guo, D.; Agliardi, M.; Mocking, T. A. M.; Kars, R.; Pham, T. P.; Xia, L.; de Vries, H.; Brussee, J.; Heitman, L. H.; IJzerman, A. P. Agonists for the adenosine $A_{1}$ receptor with tunable residence time. A case for nonribose 4-amino-6-aryl-5-cyano-2thiopyrimidines. J. Med. Chem. 2014, 57, 3213-3222.

(21) Chaplen, P.; Slack, R.; Wooldridge, K. R. H. 843. Isothiazoles. Part VII. Quaternary isothiazoles. J. Chem. Soc. 1965, 4577-4578.

(22) Viira, B.; Selyutina, A.; García-Sosa, A. T.; Karonen, M.; Sinkkonen, J.; Merits, A.; Maran, U. Design, discovery, modelling, synthesis, and biological evaluation of novel and small, low toxicity striazine derivatives as HIV-1 non-nucleoside reverse transcriptase inhibitors. Bioorg. Med. Chem. 2016, 24, 2519-2529.

(23) Rudorf, W.-D.; Augustin, M. Acylketen-S,S- und Acylketen$\mathrm{S}, \mathrm{N}$-acetale als Bausteine für Heterocyclen: 5-Cyanopyrimidine. J. Prakt. Chem. 1978, 320, 576-584.

(24) Suda, A.; Kawasaki, K.-I.; Komiyama, S.; Isshiki, Y.; Yoon, D.O.; Kim, S.-J.; Na, Y.-J.; Hasegawa, K.; Fukami, T. A.; Sato, S.; Miura, T.; Ono, N.; Yamazaki, T.; Saitoh, R.; Shimma, N.; Shiratori, Y.; Tsukuda, T. Design and synthesis of 2-amino-6-(1H,3H-benzo[de]isochromen-6-yl)-1,3,5-triazines as novel Hsp90 inhibitors. Bioorg. Med. Chem. 2014, 22, 892-905.

(25) Longstreet, A. R.; Campbell, B. S.; Gupton, B. F.; McQuade, D. $\mathrm{T}$. Improved synthesis of mono- and disubstituted 2-halonicotinonitriles from alkylidene malononitriles. Org. Lett. 2013, 15, 5298-5301.

(26) Teague, S. J. Synthesis of heavily substituted 2-aminopyridines by displacement of a 6-methylsulfinyl group. J. Org. Chem. 2008, 73, 9765-9766.

(27) Doebelin, C.; Wagner, P.; Bertin, I.; Simonin, F.; Schmitt, M.; Bihel, F.; Bourguignon, J.-J. Trisubstitution of pyridine through sequential and regioselective palladium cross-coupling reactions affording analogs of known GPR54 antagonists. RSC Adv. 2013, 3, 10296-10300.

(28) Capaldi, C.; Armani, E.; Hurley, C.; Avitabile-Woo, B. G.; Lanaro, R.; Jennings, N. S. (4-(([1,2,4]Triazolo[4,3-A]pyridine-6yl)oxy)-1,2,3,4-tetrahydronaphthalen-1-yl) ureido derivatives as anti- inflammatory P38 MAPK inhibitors for treating diseases of the respiratory tract. World Patent WO2018224423, December 13, 2018.

(29) Kim, Y. K.; Park, S. Y.; Joo, H. W.; Choi, E. S. Biaryl derivatives as GPR120 agonists. World Patent WO2014209034, December 31, 2014.

(30) Pevet, I.; Brulé, C.; Tizot, A.; Gohier, A.; Cruzalegui, F.; Boutin, J. A.; Goldstein, S. Synthesis and pharmacological evaluation of thieno[2,3-b]pyridine derivatives as novel c-Src inhibitors. Bioorg. Med. Chem. 2011, 19, 2517-2528.

(31) Roch, J.; Muller, E.; Narr, B.; Nickl, J.; Haarmann, W. 3-Amino4-phenyl-6-piperidino-1H-pyrazolo[3,4-B]-pyridines and salts thereof. U.S. Patent US4,260,621, April 7, 1981.

(32) Hamidi, H.; Lilja, J.; Ivaska, J. Using xCELLigence RTCA instrument to measure cell adhesion. Bio-Protoc. 2017, 7, No. e2646.

(33) Chun, E.; Thompson, A. A.; Liu, W.; Roth, C. B.; Griffith, M. T.; Katritch, V.; Kunken, J.; Xu, F.; Cherezov, V.; Hanson, M. A.; Stevens, R. C. Fusion partner toolchest for the stabilization and crystallization of G protein-coupled receptors. Structure 2012, 20, 967-976.

(34) Sherman, W.; Day, T.; Jacobson, M. P.; Friesner, R. A.; Farid, R. Novel procedure for modeling ligand/receptor induced fit effects. J. Med. Chem. 2006, 49, 534-553.

(35) Xu, F.; Wu, H.; Katritch, V.; Han, G. W.; Jacobson, K. A.; Gao, Z.-G.; Cherezov, V.; Stevens, R. C. Structure of an agonist-bound human $\mathrm{A}_{2 \mathrm{~A}}$ adenosine receptor. Science 2011, 332, 322-327.

(36) van Veldhoven, J. P. D.; Chang, L. C. W.; von Frijtag Drabbe Künzel, J. K.; Mulder-Krieger, T.; Struensee-Link, R.; Beukers, M. W.; Brussee, J.; IJzerman, A. P. I. A new generation of adenosine receptor antagonists: from di- to trisubstituted aminopyrimidines. Bioorg. Med. Chem. 2008, 16, 2741-2752.

(37) Kabsch, W. Integration, scaling, space-group assignment and post-refinement. Acta Cryst. 2010, 66, 133-144.

(38) Vonrhein, C.; Tickle, I. J.; Flensburg, C.; Keller, P.; Paciorek, W.; Sharf, A.; Bricogne, G. Advances in automated data analysis and processing within autoPROC, combined with improved characterisation, mitigation and visualisation of the anisotropy of diffraction limits using STARANISO. Acta Cryst. 2018, A74, a360.

(39) McCoy, A. J.; Grosse-Kunstleve, R. W.; Adams, P. D.; Winn, M. D.; Storoni, L. C.; Read, R. J. Phaser crystallographic software. J. Appl. Cryst. 2007, 40, 658-674.

(40) Afonine, P. V.; Grosse-Kunstleve, R. W.; Echols, N.; Headd, J. J.; Moriarty, N. W.; Mustyakimov, M.; Terwilliger, T. C.; Urzhumtsev, A.; Zwart, P. H.; Adams, P. D. Towards automated crystallographic structure refinement with phenix.refine. Acta Cryst. 2012, 68, 352367.

(41) Bricogne, G.; Blanc, E.; Brandl, M.; Flensburg, C.; Keller, P.; Paciorek, W.; Roversi, P.; Sharff, A.; Smart, O. S.; Vonrhein, C.; Womack, T. O. BUSTER version 2.11.7; Global Phasing Ltd.: Cambridge, United Kingdom 2017.

(42) Park, J. H.; Kim, Y. K.; Lui, J. H.; Yu, E. S.; Lee, H. I.; Jung, H. $\mathrm{K}$. Organic optoelectronic device and display apparatus. U.S. Patent US2,017,331,067, November 16, 2017.

(43) Reimschuessel, H. K.; McDevitt, N. T. Infrared spectra of some 1,3,5-triazine derivatives. J. Am. Chem. Soc. 1960, 82, 3756-3762.

(44) Joshua, C. P.; Rajan, V. P. Interaction of dicyandiamides with thioamides: Formation of 6-Alkyl(or aryl)-4-amino(or arylamino)1,3,5-triazine-2-thiols and amidino(or aryamidino)thioureas. Aust. J. Chem. 1972, 27, 2627-2634.

(45) Fryszman, O. M.; Lang, H.; Lan, J.; Chang, E.; Fang, Y. 5Membered heterocycle-based P38 kinase inhibitors. World Patent WO2005009973, February 3, 2005.

(46) Borroni, E.; Hubert-Trottmann, G.; Kilpatrick, G.; Norcross, R. Adenosine receptor ligands and their use in the treatment of disease. U.S. Patent US20,010,027,196, October 4, 2001.

(47) Perez, M. A.; Soto, J. L.; Carrillo, J. R. A simple, unambiguous synthesis of 2-amino-4-oxo- and -4-thioxo-3,4-dihydropyrimidine-5carbonitriles. Synthesis 1983, 5, 402-404. 
(48) Peseke, K.; Suarez, J.; Quincoces, J. Push-pull-butadiene; Synthese von 2-Amino-4-aryl(fur-2-yl)-6-methylthio-pyridin-3-carbonitrilen. Zeitschrift fur Chemie 1983, 23, 404-405.

(49) Mello, J. V.; Finney, N. S. Convenient synthesis and transformation of 2,6-dichloro-4-iodopyridine. Org. Lett. 2001, 3, $4263-4265$.

(50) Smith, P. K.; Krohn, R. I.; Hermanson, G. T.; Mallia, A. K.; Gartner, F. H.; Provenzano, M. D.; Fujimoto, E. K.; Goeke, N. M.; Olson, B. J.; Klenk, D. C. Measurement of protein using bicinchoninic acid. Anal. Biochem. 1985, 150, 76-85.

(51) Xi, B.; Yu, N.; Wang, X.; Xu, X.; Abassi, Y. The application of cell-based label-free technology in drug discovery. Biotechnol. J. 2008, 3, 484-495.

(52) Yu, N.; Atienza, J. M.; Bernard, J.; Blanc, S.; Zhu, J.; Wang, X.; $\mathrm{Xu}, \mathrm{X}$.; Abassi, Y. A. Real-time monitoring of morphological changes in living cells by electronic cell sensor arrays: an approach to study G protein-coupled receptors. Anal. Chem. 2006, 78, 35-43.

(53) Schrödinger, LLC. Small-Molecule Drug Discovery Suite 2018-4; Schrödinger, LLC: New York, 2018.

(54) Jacobson, M. P.; Pincus, D. L.; Rapp, C. S.; Day, T. J. F.; Honig, B.; Shaw, D. E.; Friesner, R. A. A hierarchical approach to all-atom protein loop prediction. Proteins 2004, 55, 351-367.

(55) Schrödinger, LLC. LigPrep Schrödinger Release 2019-1; Schrödinger, LLC: New York, 2019.

(56) Schrödinger, LLC. The PyMOL Molecular Graphics System, 2.2.2; Schrödinger, LLC: New York, 2018.

(57) Cheng, Y.-C.; Prusoff, W. H. Relationship between the inhibition constant $\left(\mathrm{K}_{\mathrm{I}}\right)$ and the concentration of inhibitor which causes 50 per cent inhibition $\left(\mathrm{I}_{50}\right)$ of an enzymatic reaction. Biochem. Pharmacol. 1973, 22, 3099-3108.

(58) Kourounakis, A.; Visser, C.; de Groote, M.; IJzerman, A. P. Differential effects of the allosteric enhancer (2-amino-4,5-dimethyltrienyl)[3-trifluoromethyl phenyl]methanone (PD81,723) on agonist and antagonist binding and function at the human wild-type and a mutant (T277A) adenosine $A_{1}$ receptor. Biochem. Pharmacol. 2001, 61, 137-144. 